Florida International University FIU Digital Commons

FIU Electronic Theses and Dissertations

University Graduate School

3-28-2013

\title{
Spiritual Violence: Queer People and the Sacrament of Communion
}

Sabrina Diz

Florida International University, dizsabrina@gmail.com

DOI: $10.25148 /$ etd.FI13042901

Follow this and additional works at: https:// digitalcommons.fiu.edu/etd

Part of the History of Christianity Commons, Lesbian, Gay, Bisexual, and Transgender Studies Commons, and the Religious Thought, Theology and Philosophy of Religion Commons

\section{Recommended Citation}

Diz, Sabrina, "Spiritual Violence: Queer People and the Sacrament of Communion" (2013). FIU Electronic Theses and Dissertations. 882.

https://digitalcommons.fiu.edu/etd/882

This work is brought to you for free and open access by the University Graduate School at FIU Digital Commons. It has been accepted for inclusion in FIU Electronic Theses and Dissertations by an authorized administrator of FIU Digital Commons. For more information, please contact dcc@fiu.edu. 


\title{
FLORIDA INTERNATIONAL UNIVERSITY
}

Miami, Florida

\section{SPIRITUAL VIOLENCE: QUEER PEOPLE AND THE SACRAMENT OF COMMUNION}

\author{
A thesis submitted in partial fulfillment of the \\ requirements for the degree of \\ MASTER OF ARTS \\ in \\ RELIGIOUS STUDIES \\ by
}

Sabrina Diz

2013 

To: Dean Kenneth G. Furton

College of Arts and Sciences

This thesis, written by Sabrina Diz, and entitled Spiritual Violence: Queer People and the Sacrament of Communion, having been approved in respect to style and intellectual content, is referred to you for judgment.

We have read the thesis and recommend that it be approved.

Christine Gudorf

Oren Stier

Whitney Bauman, Major Professor

Date of Defense: March 28, 2013

The thesis of Sabrina Diz is approved.

Dean Kenneth G. Furton

College of Arts and Sciences

Dean Lakshmi N. Reddi

University Graduate School

Florida International University, 2013 


\section{ACKNOWLEDGMENTS}

I would like to thank my committee for their direction, support, and patient guidance throughout the last two years. Dr. Bauman, in my very first year made an immediate impression with his knowledge in the areas of our shared interests and I feel fortunate to have him on my committee as my Major professor. To Dr. Stier, although it felt like a last resort add-in, his help was instrumental in motivating me with heavy criticism that was desperately needed. Thanks for being "ruthless". I would like to especially thank Dr. Gudorf for her help, guidance, as well as for being brilliant and forthcoming.

I would also like to thank my lifelong friend Beth Culler for her love and support. And, lastly, special heartfelt thanks to my mother, Esperanza Diz, and my two nieces, Vannessa and Tatianna Diz; all of whom inspire me every day. 


\section{ABSTRACT OF THE THESIS \\ SPIRITUAL VIOLENCE: QUEER PEOPLE AND THE SACRAMENT OF \\ COMMUNION}

by

Sabrina Diz

Florida International University, 2012

Miami, FL

Professor Whitney Bauman, Major Professor

This thesis addresses spiritual violence done to queer people in the sacrament of Communion, or Eucharist, in both Protestant and Roman Catholic churches in the U.S. Rooted in the sexual dimorphic interpretation of Genesis, theologians engendered Christianity with sexism and patriarchy, both of which have since developed into intricate intersections of oppressions. Religious abuse is founded on the tradition of exclusionary practices and is validated through narrow interpretations of Scripture that work to reassert the authority of the experiences of the dominant culture. The resultant culture of oppression manifests itself in ritualized spiritual violence. Queer people are deemed "unworthy" to take 'the body and blood of the Christ' and, in fact, are excluded altogether. This "unworthiness" is expressed as spiritual violence against queer people who are shunned and humiliated, internalize hateful messages, and are denied spiritual guidance or life-affirming messages. By "queering" Scripture, or reading the Bible anew through a framework of justice, queer people have begun to sacramentalize their experiences and reclaim their place at the table. 


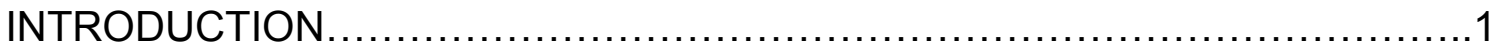

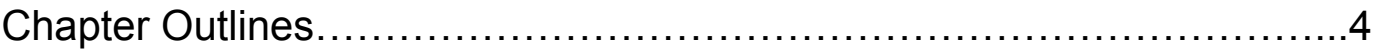

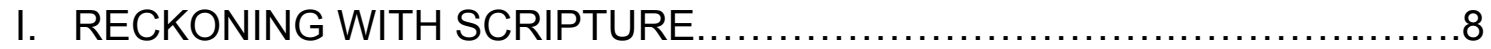

The Clobber Passages................................................ 10

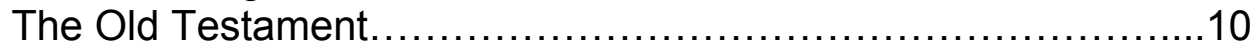

The New Testament...............................................

Sexual Dimorphism in Genesis ........................................

II. AN EXPLANATION OF EUCHARIST ......................................46

The Importance of Communion.........................................50

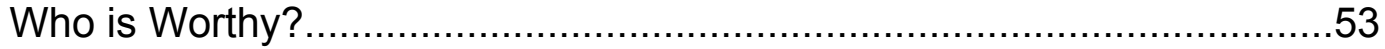

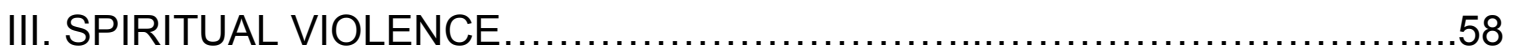

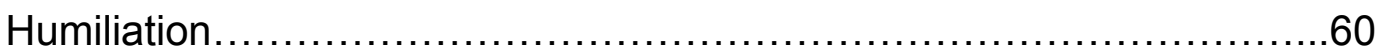

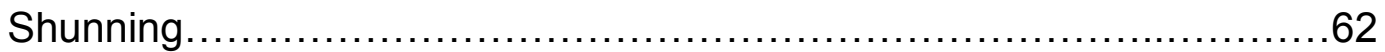

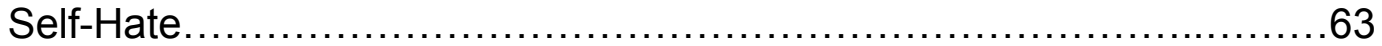

Polluting Spiritual Resources.......................................6

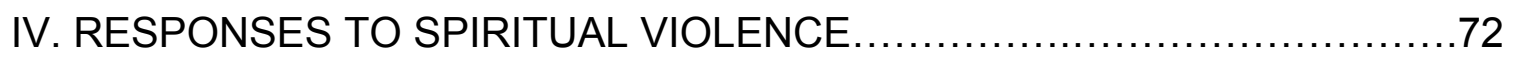

Coming Out as Sacrament........................................... 75

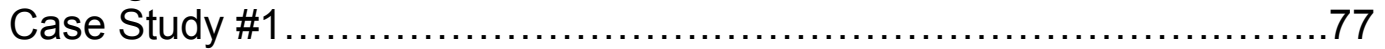

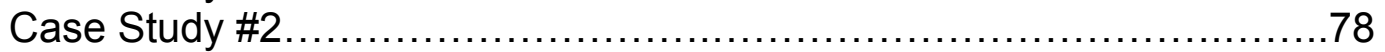

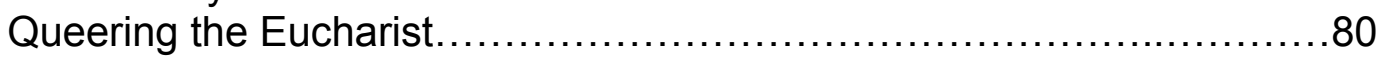

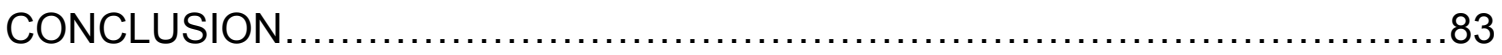

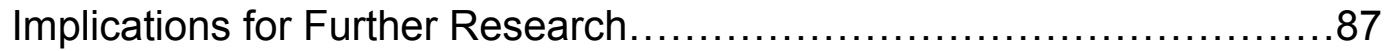

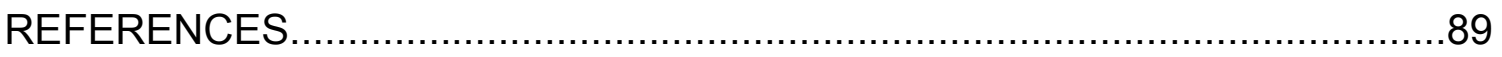





\section{INTRODUCTION}

Christianity has a colorful history with the different types of oppression and

violence it has condoned, even incited. ${ }^{1}$ In response to injustices there have been various moments in the last two thousand years when Christianity has doubled back to correct mistranslations of the Bible that science and social praxis have revealed to be inaccurate misunderstandings, unjust, and even cruel. In many ways, the faith can be seen as learning from itself, cultivating the faith in remembrance and reconcilement. Slavery, apartheid, the subjugation of women, and other forms of violence found in the Bible have since been recognized by Christian denominations, both Roman Catholic as well as Protestant, as not compatible with Christian teaching. There are other forms of oppressions and forms of violence that most Christian churches have yet to recognize or actively engage in eliminating such as, cis-hetero-patriarchy: the intersection of various oppressions that has ultimately resulted in the demonization of queer people and their marginalization from church community. ${ }^{2}$ What all of these forms of oppressions have in common is that, at one time or another, they were believed

\footnotetext{
${ }^{1} \mathrm{~J}$. Harvey in Civilized Oppression defines oppresion as a force that is rooted in morally inappropriate relationships, which underlie and contribute to tangible harms, 1999, 37.

${ }^{2}$ The term "queer" is used here in place of the nomenclature that far exceeds acronyms in use today. It refers to sexual orientation that differs from the norm, which can be categorized as "not heterosexual," gender non-conforming or gender variant. The term "queer" implies subversion of normalizing powers through non-normative practices. It can also be implied as the opposite of elitism and exceptionalism; heteropatriarchy is the result of hierarchal social relations in a society dominated by cisgender, heterosexual, gender-conforming men that promotes cisgender, heterosexual relationships as dominant over any other type of relationship, and cisgender males as dominant over cisgender females, with cisgender individuals (heterosexual or queer) privileged over transgender or gender-non-conforming individuals. Cis-hetero-patriarchy results in the hierarchal organization of the intersecting oppressions: homophobia, transphobia, heteronormativity and heterosexism. (see page 38 for a broader definition in footnotes)
} 
to be supported by Scripture. What concerns this thesis is, first, the spiritual violence in church life as is currently experienced by queer people of faith in the majority of U.S. churches and, secondly, the responses by queer people of faith that challenge their exclusion from church community and communion.

Queer people have and continue to suffer oppression and violence under institutionalized religion. In Christianity, the oppression manifests itself in the demonization and marginalization of queer people in both Roman Catholic and Protestant denominations, manifesting as spiritual violence in the exclusion of queer people from the faith. Specifically looking at churches in the U.S., the large majority of people subscribe to a Christian tradition that excludes queer people from participating in the sacraments, fundamental tenets of the Christian faith. The source passages from the Bible will be analyzed to understand the arguments in support of the oppression. These passages, as well as pieces of the history and cultural contexts of the passages, need to be analyzed to understand the exclusion and resultant spiritual violence. The sacrament of Communion, a central symbol of the faith, is a call for people of Christian faith to gather in fellowship with others and with God and so it is critical to analyze the theology that supports the sacramental liturgy and understand that alongside the arguments in support of exclusion of queer people from church life, as well as the arguments in support of the exclusion of queer people from the sacrament of Communion. This exclusion from spiritual resources, church community, and participation in the sacraments results in violence that is done to the spirit and spirituality of queer people. This thesis brings together the history of exclusionary 
Bible passages, with Scriptural support for the sacrament, to argue that Christianity was not founded on exclusionary practices. Indeed, a "queer" Christianity is the radically inclusive faith of the early Church. In response to the abuses of religious groups, queer people have reclaimed the sacraments, and regained their place at the Lord's Table.

In this thesis, mainstream churches refer to the Roman Catholic Church, Fundamentalist churches, and Protestant churches that condone or uphold exclusionary practices against queer people in church life and liturgy. ${ }^{3}$ Fundamentalist churches may not have an overwhelming number of members, but they are known to publicly and actively work against queer people's rights. Protestantism has just as many affirming branches, like many Presbyterians or Episcopalians that allow everyone to be a member, even to be ordained. The Christian denominations that have the most members in the United States, such as Catholicism, Baptists, or United Methodists, however, believe homosexuality and Christian identity are mutually exclusive and exclude queer people from participation in Communion, or Eucharist. ${ }^{4}$ Other denominations, such as the Lutherans, in policy have stated they are open and affirming; however, this is still

\footnotetext{
3 "Mainstream" or "exclusionary churches" refers to the dominant religious groups in the U.S. that discriminate against queer people, unless when speaking of specific church group or denomination.

4 "Affirming" or "open and affirming" refers to churches that do not exclude queer people from church life and liturgy, or membership and ordainment; Catholics prefer Eucharist, United Methodists do not have a preference.
} 
a point of heated debate that has divided many Lutheran groups. ${ }^{5}$ Baptist

churches are the only one of the church branches mentioned here that regard the ritual of the elements as an "ordinance", instead of as a "sacrament".

Interestingly, they still agree with exclusionary practices. American Baptist and Southern Baptist churches, which make up the majority of the Baptist membership, do not allow queer people to take communion, or in their tradition, the Lord's Supper. ${ }^{6}$ There are still other branches of Christianity in the United States that could be included, such as Pentecostals or Mormons, but both of these have specific ties with "hate campaigns" and would need more space for discussion than this thesis allows. Despite the liturgical differences between the different religious groups, exclusionary practices exerted by any church body is damaging and inflicts spiritual violence.

\section{Chapter Outlines}

Chapter one of the thesis offers a brief introduction to queer theology to introduce the foundation and goals. The chapter argues that interpretations of Bible narratives reflect the exclusive experiences of the most privileged in history; cisgender, heterosexual, gender-conforming men. There are nine passages in the Bible which are routinely used to "clobber" (homo)sexuality from the pulpit. These "clobber passages" are explored through "queer" modern scholarship. The

\footnotetext{
${ }^{5}$ Evangelical Lutheran Church of America 2009 there are many periodicals that report on the divisive nature of the "gay" argument, the ELCA is also careful to point out that they do, indeed, allow queer people into membership.

${ }^{6}$ Adherents 2005 offers population data per denominaton and per religion; American Baptist Churches USA n.d.; Baptists require Baptism before receiving the elements.
} 
first four of the nine clobber passages explored are found in the Old Testament (OT); the Story of Sodom and Gomorrah (Genesis 19:1-5), two are found in Leviticus (Leviticus 18-22, and 20:13), and one in Deuteronomy (22:5). In the New Testament (NT) the other four passages can be found in the writings of Paul in his letters to the Romans (1:21-31), letters to the Corinthians (6:9-10), and in 1 Timothy (1:9-10). The last can be found in the book of Jude (1:6-7), but which will be analyzed alongside the story of Sodom in the Old Testament section of the chapter. Along with these passages, sexual dimorphism in Genesis is included in my thesis as it has caused intricate intersections of oppressions in the Bible that manifest today in the forms of homophobia, heterosexism, and heteronormativity. Investigations conducted over the past thirty years by historians, theologians, and renowned interdisciplinary scholars have produced progressive and justiceseeking theological discourse. Through the various frameworks of interpretation, offered here is a sampling of linguistic, etymological, cultural, historical, and ethical arguments that are deemed as "queer" scholarship because they challenge the traditional theological discourse.

Chapter two begins by specifically looking at the Christian sacrament of communion $^{7}$. Most Protestant churches in the United States have policies that disagree firmly with "homosexuality." The Roman Catholic Church views

\footnotetext{
${ }^{7}$ Also known as "Eucharist", "the Lord's Supper" and "Holy Communion" by Protestants, the terms here are largely used interchangeably except when speaking of specific churches that may have a preference.
} 
homoeroticism as one of the "mortal sins" that excludes you from the Eucharist. ${ }^{8}$ These messages are hostile and cruel, and they only succeed in disconnecting queer people from religious resources and spiritual nourishment. Chapter two explores how the sacrament, a gift from Jesus to all believers, is governed by church to decide and preside over who is worthy or not.

Chapter three defines religious oppression and marginalization as spiritual violence or religious abuse. Illustrating the effects of this violence as experienced by queer people that have been marginalized and oppressed by mainline churches, the components are classified and explained as elements that make up spiritual violence, such as, shunning and humiliation, the inculcation of selfhate, and the polluting of spiritual resources. Ritualized spiritual violence is defined as the harm done to people through the exclusion from sacred rituals, in this case Eucharist. The ritual violence is shown to be a direct result of the misuse of the Bible against queer people as shown in chapter one. Ritualized spiritual violence has devastating results for people of faith, and also for all Christians who have been indoctrinated to believe that God favors a culture of exclusion.

Chapter four will look at personal stories of queer people and how sacraments have been "queered." The new sacrament, that of "coming out", will

\footnotetext{
${ }^{8}$ The focus will remain on Roman Catholicism versus Orthodox, or Eastern Orthodox, since it is the most common form of Catholicism in the United States at the time of this paper.
} 
be explained and I will offer a glimpse into the modern theological productions by queer people. It looks at two short biographies and offers a queer deconstruction to illustrate transgressive properties that are inherent in queer people and how their varied experiences in Eucharist can be seen as subversive. Looking at queer people's stories this paper hopes to bring into the discussion how Communion, or Eucharist, has been queered and reclaimed in different ways. ${ }^{9}$

\footnotetext{
${ }^{9}$ The word "queer" can also be used as an adjective, or in this case a verb. As an adjective it refers to something or someone that is non-normative and has an element of subverting authority or power. As a verb it can be used as a way of understanding through deconstruction, and "to queer" something means to apply the elements of non-normativity and subversion to some thing/idea/place.
} 


\section{RECKONING WITH SCRIPTURE}

It is impossible to talk about queer theology without an explanation of the word "queer". As is employed here, the word "queer" can be used as an umbrella term to include the varieties of words that exist to describe nonnormative sexual and gender identities. These non-normative identities deviate from the dominant sexualities or gender norms, but include allies that "stand in solidarity with their queer [siblings]. ${ }^{10}$ The term "queer" has been reclaimed, or rescued from misuse. In this use, queer is not only non-normative, but also comes to align itself with the opposition to societal norms. Queer is also the foundational name for the emerging field of "queer theory", which focuses on deconstructing normalizing boundaries and the destabilization of categories of gender and sex. Queer theology is made up, partly, by theological discussions that challenge, question, or confront the normalizing forces that have produced traditional interpretations of Scripture, especially in regards to gender and sexuality. Modern Biblical theology is shedding new light on these passages, allowing people to understand the history, practicality, and/or the philosophy that forms the context of the clobber passages. ${ }^{11}$

\footnotetext{
${ }^{10}$ Cheng, Radical Love: An Introduction to Queer Theology, NY: Seabury Books, 2011, 3.

${ }^{11}$ Elizabeth Schüssler Fiorenza, In Memory of Her: A Feminist Theological Reconstruction of Christian origins, 1983, 4-6; Yarbrough 1997 International Standard Bible Encyclopedia.
} 
The "clobber passages" are a handful of passages in the Bible that are used as the Scriptural basis for the discrimination of an entire group of people. ${ }^{12}$ Colloquially "clobber" passages are so-called because the passages have been used to "clobber" homosexuality from the pulpit. Although homophobia and heterosexism has dominated the Christian tradition, the demonization of queer people in the U.S. increased drastically after the word "homosexual" was added into the Bible in $1946 .^{13}$ The legacy of discrimination from the church continues to keep queer people of faith marginalized from Christian life and community. Fortunately, more and more "out" queer people of faith have begun to ask questions, specifically in regards to Scripture and its history. Though thirty years ago there was a scarcity of affirming resources, queer people can now follow the scholarly work of queer historians, authors, sociologists, psychologist, and religious leaders, all of who are viewed as courageous pioneers in their areas of focus and continue to work on the many questions still unanswered. The following section will look at where the clobber passages are found in contemporary Bibles and explore the emergent queer scholarship reflecting different theological backgrounds that challenge, question, provoke, and/or confront oppression in Christianity.

\footnotetext{
${ }^{12}$ Genesis 19:1-5; Leviticus 18:22; Leviticus 20:13; Deuteronomy 23:17; Romans 1:21-31; 1 Corinthians 6:9-10; 1 Timothy 1:9-10; Jude 1:6-7;Deuteronomy 23:17.

${ }^{13}$ Boswell Christianity, Social Tolerance, and Homosexuality 1980; John J. McNeil, The Church and the Homosexual, NY: Beacon Press, 1976.
} 


\section{The Clobber Passages}

\section{The Old Testament:}

\section{Genesis 19:1-5}

19 The two angels came to Sodom in the evening, and Lot was sitting in the gateway of Sodom. When Lot saw them, he rose to meet them, and bowed down with his face to the ground. ${ }^{2}$ He said, "Please, my lords, turn aside to your servant's house and spend the night, and wash your feet; then you can rise early and go on your way." They said, "No; we will spend the night in the square." ${ }^{3}$ But he urged them strongly; so they turned aside to him and entered his house; and he made them a feast, and baked unleavened bread, and they ate. ${ }^{4}$ But before they lay down, the men of the city, the men of Sodom, both young and old, all the people to the last man, surrounded the house; ${ }^{5}$ and they called to Lot, "Where are the men who came to you tonight? Bring them out to us, so that we may know them." ${ }^{14}$

The story of Sodom and Gomorrah, in modern times, is associated with the vice of "sodomy", or as is now generally understood, the vice of "homosexuality." The passage reads that the men of the town desired to rape male angels and has been interpreted to be a condemnation of (homo)sexuality. However, Genesis 19 was not originally intended to draw attention to (homo)sexuality. The word homosexual, coined from a Greek prefix and a Latin root in 1892 by a German psychologist, means "of one sex" or "of same sex" and has no connection to the story of Sodom, nor does the Hebrew or Greek of the story's day have any word that means "homosexual", nor "gay", or even someone that is attracted to the same sex. The story of Sodom and the etymology of the word "sodomite" are interesting and complex. Mark D. Jordan, a theologian and

\footnotetext{
${ }^{14}$ New Revised Standard Version (NRSV).
} 
historian, has written extensively on the story of Sodom. ${ }^{15}$ In fact, Jordan writes, "Sodomy is as much a theological category as trinity, incarnation, sacrament, or papal infallibility." ${ }^{\text {16 }}$ In agreement with Jordan's understanding of the depth and breadth of the history of "sodomy", it can be understood that this mistranslation and consequent promotion of imposed vices are not easily dismissed here. The following section attempts to give a sense of how the vices of Sodom have been wholly altered.

The Old Testament describes Sodom as a city full of pride, inhospitality, and a number of other such evils, but never mentions homoeroticism. ${ }^{17}$ The connection to sexual sin in the story of Sodom stems from the particular use of "yada", the Hebrew word meaning "to know." This word is also used as a euphemism for sex, as shown in Genesis when Adam "knew" Eve and she conceived. ${ }^{18}$ In the story (all of) the men of Sodom demand "to know" the Angels that are hidden in Lot's house. Lot instead offers his two virgin daughters. The townsmen refuse the virgins, attempt to harm the foreigners, and are then stricken blind by the Angels. In a very similar story in Judges 19:13-27, a foreigner and his concubine entreat a townsperson for shelter for the night. The townsmen come and demand to know the foreigners. The concubine is offered

\footnotetext{
${ }^{15}$ Mark D. Jordan The Invention of Sodom, Chicago: University of Chicago Press, 1997; Mark D. Jordan, The Silence of Sodom, Chicago: University of Chicago Press, 2000; Mark D. Jordan, Ethics of Sex MA: Blackwell Publishing, 2002.

16 Mark D. Jordan The Invention of Sodom, Chicago: University of Chicago Press, 1997, 29.

${ }^{17}$ Isaiah 1:9, 13:19; Jeremiah 49:18, 50:40; Amos 4:11; Zephaniah 2:9.

${ }^{18}$ Genesis $4: 1 ; 17: 25$.
} 
to appease the men. She is raped all night and dies at the door of the house. Interestingly, the story of Sodom, where all of the men of the town attempt to rape the Angels carries the stigma of homosexuality, while the story in Judges, where the men of the town attempt to rape another man, does not. The story in Judges has never been recorded to be associated with Sodom or any type of homoeroticism, so how did the story of Sodom and Gomorrah become associated with (homo)sexuality?

From his chronological trajectory of the word "sodomite", Jordan concludes that the "complicated and disturbing story [of Sodom] was simplified until it became the story of the punishment of a single sin." ${ }^{19}$ As Jordan explains, the city once stood as a symbol for a multiplicity of sins, but over time Sodom became reduced to a "singular sin", that of homosexuality. What is interesting is that the connection between Sodom and "homosexuality" actually did not occur until the eleventh century. Peter Damian (1007-1072), an author and theologian, in a historically and theologically complicated analogy to blasphemy, made the association between Genesis and Jude 1-7. Because of Jude and Genesis' similar use of the phrase unnatural lust, Damian makes the association between the passages that they must be related. ${ }^{20}$ Jude's letter contains similar language because both narratives, the story of Sodom and the letter from Jude, talk about both Angels and sexual lust; however, the context of the letter as a whole is principally preaching against false teachings. Instead, this passage in Genesis

\footnotetext{
${ }^{19}$ Mark D. Jordan, The Invention of Sodom, Chicago: University of Chicago Press, 1997, 13.

20 Jordan, Invention of Sodomy, 29-37; in other Bible versions "strange flesh".
} 
has been used to support heterosexism and homophobia by imposing constructed vices on the story of Sodom, which have served to perpetuate homophobia and transphobia ever since.

\section{Jude 1:6-7}

6 And the angels who did not keep their own position, but left their proper dwelling, he has kept in eternal chains in deepest darkness for the judgment of the great day. 7 Likewise, Sodom and Gomorrah and the surrounding cities, which, in the same manner as they, indulged in sexual immorality and pursued unnatural lust, serve as an example by undergoing a punishment of eternal fire.

The association Damian made was between the similar usage of the phrase strange flesh that was recorded in the story of Sodom and also recorded in the letter from Jude. Between the two rape narratives referred to earlier (Genesis and Judges) the reference to strange flesh is recorded only in the Sodom narrative and is not present in the narrative in Judges. So, what is Jude referring to or comparing? Jude writes that the men of Sodom went after "strange flesh" or "unnatural lust." ${ }^{21}$ In response, this thesis argues that Jude 1:6-7 supports the idea that homosexuality was not the object of "unnatural flesh" in

\footnotetext{
${ }^{21}$ In yet another example of the diverse interpretations available, one that reaches back before Jesus to the Testament of Naphtali (c. 109-106 B.C.E.), there is a view that proposes that Jude here alludes to a legend in the Jewish tradition where by the women of Sodom and the angels engaged in intercourse. Derrick Sherwin Bailey, Homosexuality and Western Christian Tradition, 13.
} 
Genesis. ${ }^{22}$ (19:1-5) Just as the men of Sodom attempted to go after "strange flesh" (meaning that of the angels), in Jude the Angels are also accused of attempting to go after "strange flesh" (meaning that of humans). Both the men of the city of Sodom and the Angels that left their dwelling place were punished because they disobeyed God. The men of Sodom were punished because they lusted after the Angels' "flesh" and the Angels who left their dwellings were punished because they lusted after the "flesh" of humans. It is unclear how or why Damian connected homoeroticism to both of these passages. Clearly, sex between humans and Angels does not constitute homoerotic behavior for us today. Early Christianity also did not refer to the story of Sodom as a reference to sex or sexuality. So how did Peter Damian come to draw such a strange connection?

Damian is not the only person to make associations between passages in the Bible; in fact this is common practice. However, when there is an oppressed group in question, discrimination can further obscure or promote mistranslations. "Strange flesh", in Jude as well as in the story of Sodom, refers to the difference between the flesh of humans and the flesh of angels. It is, and no doubt, was queer to interpret from Jude 1:6-7 that the Angels were engaging in sexual misconduct with humans because it undermines the purity or sanctioned place of the Angels as well as the ecclesial authorities of the day that did not

\footnotetext{
22 Originally, after reading the passages and comparing stories I concluded that Jude does not refer to homosexuality, but about the crossbreeding and fornication between the Angel and Human species. Jordan's writings also disagree that Jude supports anti-gay views, but we both equally believe that Jude supports the fact that Sodom does not have anything to do with homoerotic behavior.
} 
acknowledge this as part of their theology. The interpretation of Jude that allows for Angels fornicating with humans also blurs the norms of sexuality and status of Damian's day. The sex of the Angels is neither mentioned nor referred to as male or female, and so a space for a third sex is created. In light of this, the category of gender therefore, is also unintelligible because it was transgressed by the Angels. These are all areas in which past theologians might not have wanted to venture far into a thousand years ago. This might have been the case with Damian. Sex, sexuality, gender, and gender roles were set and "God-given" and governed by the church. Even though to deny the multiplicity of interpretations that this modern exegesis of Jude offers would be an example of what Jude is preaching against: the word of God becoming hidden from Christians by narrow interpretations (i.e., "false teachings"), theologians like Damian were working from a particular ecclesial framework that did not contain this modern notion in their theological discourse.

In light of modern scholarship, there is a call for the Bible to continuously reflect justice-centered theology and to double back when necessary to renounce false teachings. It is important to continue to reconcile ignorance and modern scholarship. Changes and updates in the Bible is not uncommon. An example of this would be in the New King James Version (NKJV), where the word "sodomite" has been replaced with "temple prostitute" in both Deuteronomy 23:17 and 1 Kings 14:24. When Jewish scholars translated the Septuagint into Greek, Jewish scholars used the assistance of six different words for the Hebrew term "kadash," 
the Hebrew root associated with holiness. ${ }^{23}$ Jordan believes this may have been where the mistranslations began because of the inaccuracy of Greek words to convey the meaning of Hebrew terms. ${ }^{24}$ In the King James Version (1611) the word "sodomite" appeared twice to stand in for the word "kadash," however, in 1982 the NKJV was published and both uses of the word kadash were updated in that version and re-translated as "temple prostitute."

Deuteronomy 23:17

${ }^{17}$ None of the daughters of Israel shall be a temple prostitute; none of the sons of Israel shall be a temple prostitute. (this used to be translated as "sodomite")

\section{Kings 14:24}

${ }^{24}$ there were also male temple prostitutes in the land. They committed all the abominations of the nations that the LORD drove out before the people of Israel.

It is quite possible that because of the contemporary application of the term "sodomite" toward (homo)sexual people, the term kadash, previously translated into "sodomite", was changed so that it would not be confused with the use of "homosexual" employed in other passages of the Bible. Bible scholars have updated wording and translations when necessary in the past. Misconceptions and mistranslations in connection with the story of Sodom, as with all the clobber passages, deserve the same consideration.

\footnotetext{
${ }^{23}$ Boswell Christianity, Social Tolerance, and Homosexuality, 99.

${ }^{24}$ Deuteronomy 23:18; I Kings 14:24; 15:12; 22:47; 2 Kings 23:7; Hosea 4:14.
} 


\section{Leviticus 18:22}

${ }^{22}$ You shall not lie with a male as with a woman; it is an abomination.

\section{Leviticus 20:13}

${ }^{13}$ If a man lies with a male as with a woman, both of them have committed an abomination; they shall be put to death; their blood is upon them.

Leviticus is the only place in the Bible that some historians believe ever truly prohibits (homo)erotic behavior. ${ }^{25}$ While queer historians, such as Jordan, work to untie two millennia's worth of etymology to find the beginning conditions of today's confining interpretations of some biblical passages, others work to understand the historical and cultural context. Clarifying certain cultural gaps between that of the early Israelites and modern-day U.S. culture allows people to relate to the Bible in deeper ways by demystifying the existence of past cultures. Clarifying culture-bound norms allows room to make connections between the Israelites' concerns and the concerns of modern cultures, which aids Christians in deeper understandings of Bible precepts.

John Boswell, historian and author on whose work many other scholars have based their research, also offers unique insight into terminology as well as cultural context for the Old Testament. The New Revised Standard Version

\footnotetext{
${ }^{25}$ Boswell, Christianity, Social Tolerance, and Homosexuality ,100 believes that "abomination" really pointed to something ritually unclean rather than evil; L. William Countryman, Dirt, Greed, and Sex: Sexual Ethics in The New Testament and Their Implications for Today, Philadelphia: Fortress Press, 1988, 32 believes that the prohibition in Leviticus of homoerotic acts are connected to purity laws, of which are generally no longer followed by the average Christian.
} 
(NRSV) translation above is really an interpretation. English does not have a word that would do justice to the term Tô'ebâ (translated above as "abomination"); it is a culture-specific term that has lost its complexity and range throughout time. Modern day cultures, therefore, need to find a word that can closely resemble it. Tô'ebâ which is used in various parts of the Hebrew Scriptures and applied to a variety of transgressions, has traditionally been interpreted as "abomination." Tôebâ's definition is actually closer to meaning something extremely disgusting or hated, rather than abomination. "Abomination" in Christianity today is associated with a definition of "sin", which clearly has insinuations of Hell, a concept unfamiliar to early Israelites. Many scholars have made the connection between this term and ritual cleanliness, so that the eating of pork, sexual relations during menstruation, or a man engaging in anal intercourse are all connected with ritual "uncleanliness." ${ }^{26}$ Clarifying definitions of the allows scholars to understand that the Israelites did not actually view abominations similarly to what today, in Christianity, is referred to as "sin" or "abomination" in current context, but something different altogether that the passage of time has obscured. Leviticus threatens against this form of behavior with death to both parties involved, which implies that the severity of the transgression of anal intercourse between two males must have been pretty serious, and yet, other than in these two passages this admonition against homoerotic practice does not appear in the Scriptures at all.

\footnotetext{
${ }^{26}$ Leviticus 20:13, KJV; Boswell Christianity, Social Tolerance, and Homosexuality 100.
} 
To further confound the passage, many scholars understand the phrase "lies with a male as with a woman" (seen above) as an interpretation of a translation. Miškebê 'iššâ is also commonly interpreted as "the lyings of a woman." ${ }^{27}$ The first phrase "lies with a male as with a woman" seems to make an explicit statement: intercourse between two men is inherently against God. The other translation "lyings of a woman" has different implications. The "lyings of a woman" seems to compare the positions men and women take up during sex, rather than promote (hetero)sexual sex. The phrase admonishes against a man having intercourse the way a woman would have intercourse. From this point it would not be a giant leap to suspect some form of misogynism at play, especially when female-female homoeroticism is not mentioned to balance the admonition against male-male homoeroticism. To understand this prohibition better, historians are forced to look to other cultures for a better understanding of differences in sexual norms across time.

In the History of Sexuality I, Michel Foucault explains that the category "homosexual" was invented in the $19^{\text {th }}$ Century in an attempt to regulate human sexuality. ${ }^{28}$ Foucault's argument is that the construction of this category neither exhausts all forms of homoerotic sexualities throughout all cultures and time periods, nor does it define and explain homoerotic behavior as understood by the

\footnotetext{
${ }^{27}$ Saul Olyan, "And with a Male You Shall Not Lie the Lying Down of a Woman" Meaning and Significance of Leviticus 18:22 and 20:13, Journal of the History of Sexuality 5, 1994: 179-206, 180.; Countryman in Dirt Greed and Sex also interprets this as "the lyings of a woman,"( 26). Italics mine.

${ }^{28}$ Michel Foucault, History of Sexuality I. NY: Random House,1978,121.
} 
early Israelites or the early church as consistent with contemporary definitions. ${ }^{29}$ For example, Leviticus specifies that slaves must be reaped from other nations, positioning the worth of the Israelite females above the worth of females from surrounding nations that were indeed, sanctioned to be bought and used as slaves. The positioning of the worth of Israelite females above the worth of nonIsraelite females refers to an intricate hierarchy of human value that involves both sex, as understood by the ancient people in strictly male/female terms, as well as in social class (i.e. priest, slave). Today the hierarchy, or positioning of human value and worth, is different. For one, modern society no longer supports the institution of slavery. Secondly, today the hierarchy consists of other qualifiers, such as socioeconomic status, sex, and, arguably, even race and age. In summary, Foucault vehemently refuses to accept the traditional belief that there is a fixed "homosexual" identity that has remained static in definition and behavior throughout time.

Within the context of ancient Israel, in the land of Canaan, gender roles were constructed very differently than modern gender roles in the United States. An example would be the defined gender roles of the theocracies of ancient times. ${ }^{30}$ The Israelites had an intricate power system that prescribed gender roles according to sex, and constructed gender roles according to sex and status. ${ }^{31}$ Through the work of Foucault and others such as Alfred Kinsey, sexuality and

\footnotetext{
${ }^{29}$ Ibid., 121.

${ }^{30}$ Jordan, Silence of Sodom, 230-233

${ }^{31}$ It should be added that gender in Israelite times was also most likely co-constructed with other intersecting categories; this thesis only makes a point of two: sex and class.
} 
gender have been redefined and are now classified as different categories of human experience, but are also now both understood as fluid as well, meaning they will change over time and do not remain statically defined for most individuals. ${ }^{32}$ In alignment with Foucault, my thesis argues that modernity's fixed "homosexual" identity is a modern construct that was not understood in premodern times.

The author L. William Countryman in Dirt, Greed, \& Sex: Sexual Ethics in the New Testament and their Implications for Today, offers a compelling account of sexuality in the Old Testament, beginning with the concept of "purity" and the implications it has had ever since. ${ }^{33}$ He defines "purity" as "a system with the human being at or near its center. Dirt is what lies outside the system, what is perceived as not belonging in association with people of this particular society, whether that "dirt" is unfamiliar, irregular, unhealthy, or otherwise objectionable."34 The purity laws of the early Israelites, even what is considered clean or dirty, are, of course, culture-bound, especially those things that go in and out of the body. ${ }^{35}$

\footnotetext{
${ }^{32}$ Dr. Alfred Kinsey conducted famous surveys on sexuality, leading to "proving" his theory that sexuality fell within a range instead of on a strictly heterosexual/homosexual binary. Gilbert Herdt in Third Sexes and Third Genders critiques Kinsey, Freud, and Levi-Strauss because they have not reflected, in their categories of Western dimorphism, the various groupings of other cultures (35).

${ }^{33}$ Countryman, Dirt Greed and Sex, 13.

${ }^{34}$ Ibid., 13.

${ }^{35}$ These among several others. Ibid., 13.
} 
The dietary laws of Leviticus are believed to be extremely thought out and consistent, even though the average Christian in the U.S. now generally discards them. ${ }^{36}$ However, these laws were considered critical to the faith and for the continuation of the heritage ${ }^{37}$ These were staples in their culture, for when the people of Israel were in other nations, their dietary and ritual laws kept them distinct from other peoples.

The Holiness Code "holds up the ideal of an absolute separation between Israel and all that is unclean and utters a "no" to uncleanness so absolute that it is often enforced through the execution or the "cutting off" of the polluted." ${ }^{38}$ The Holiness Code is held as an ideal for the Israelites. ${ }^{39}$ It is not difficult to imagine that the strict purity laws were difficult to adhere to even twenty-five hundred years ago. The rituals kept many people out, but they were mostly meant to keep the Israelites in. Many of the rituals were intended for fellowship, such as the Passover meal, as are the sacraments today, such as the sacrament of communion.

\footnotetext{
${ }^{36}$ Ibid.,23.

${ }^{37}$ Regina Schwartz, The Curse of Cain,Chicago: University of Chicago Press, 1997, xi.; Mark D. Jordan, Ethics of Sex.

${ }^{38}$ Countryman, Dirt, Greed and Sex, 13.

39 Ibid., 23.
} 
Mary Douglas, in Purity and Danger, offers an interpretation that explains holiness as wholeness. Those that have a little leprosy are deemed "unclean", while those completely covered with leprosy are then "clean."

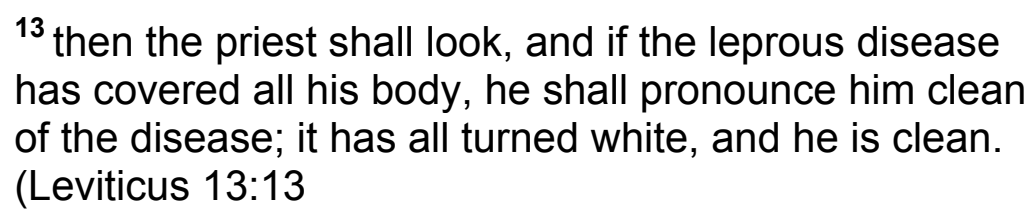

When a woman menstruates, gives birth, or bleeds outside of her menstruation period she is not in her natural, whole state and is rendered unclean. ${ }^{41}$ Along these same lines it is unclean when two things are mixed that do not belong together because it results in "confusion." ${ }^{42}$ Two animals of different breeds should not be allowed to reproduce, or a fabric should not be woven of different types of fibers. ${ }^{43} \mathrm{~A}$ man who lies with another male is mixing two things that should not be mixed. 'Purity', then, was a constructed value system that radically differs from the value system of purity appreciated today.

What is curious about Leviticus is that Christians today do not generally follow the purity laws from the OT, indeed they were abandoned by the second century. Even so, the clobber passages in Leviticus are still the foundation for modern hate-speech and homophobic discourse. Historian John Boswell states, "if religious strictures are used to justify oppression by people who regularly

\footnotetext{
${ }^{40}$ Mary Douglas, Purity and Danger: An Analysis of the Concept of Pollution and Taboo,NY: Routledge, 1966, 45; Leviticus 13:12-13.

${ }^{41}$ Leviticus 12; 15:19-30.

${ }^{42}$ Leviticus 18:23.

${ }^{43}$ Leviticus 19:19.
} 
disregard precepts of equal gravity from the same moral code, or if prohibitions which restrain a disliked minority are upheld in their most literal sense as absolutely inviolable while comparable precepts affecting the majority are relaxed or reinterpreted, one must suspect something other than religious belief as the motivating cause of the oppression. ${ }^{\text {"44 }}$ To follow the purity laws today in Leviticus would call for a radical change to the fabric of contemporary society. It is now generally understood by Christians that Leviticus was written for the people of a different culture when certain rituals and codes were followed, but do not necessarily make sense for cultures in modern times. When confronted with Leviticus, Christians also make the case that Jesus came to "fulfill" the OT, meaning that with Jesus all the old rules have been changed. Both general assumptions, the argument that Leviticus is inapplicable in modern day society and the argument that Jesus has fulfilled the OT, are accepted by mainstream churches in all other situations, except when applicable to queer people.

\section{Deuteronomy 22:5}

${ }^{5} \mathrm{~A}$ woman shall not wear a man's apparel, nor shall a man put on a woman's garment; for whoever does such things is abhorrent to the LORD your God.

The passage has been used to support the idea that God does not want men and women exchanging apparel, in other words, cross-dressing. It is especially used to condemn gender non-conforming people, trans* people, and

${ }^{44}$ Boswelll, Christianity, Social Tolerance, and Homosexuality, 7. 
other groups that do not conform to strict gender prescriptions and fixed gender roles. Countryman observes that since the prohibition and the one in the Holiness Code that restricts homoerotic male-male acts occur only once, these must have been peripheral concerns for the early people. ${ }^{45}$

According to Countryman, prohibitions made sociological sense. ${ }^{46}$ For example, Deuteronomy allows for the Israelites to give away or even sell the carrion they find to the Canaanites, but to avoid impurity the Israelites may not eat it. ${ }^{47}$ As shown, the purity system was not applicable as universal law to all people, but it was understood that each nation would have their own purity laws to abide by, by which they set their people apart from other nations. Interestingly enough, in the second century B.C.E. some Jews wished to abolish the purity laws, citing a desire to become closer to their Gentile neighbors culturally and politically. Although Jews were briefly divided on this point of contention, the dominant tradition within Judaism retained the purity codes. ${ }^{48}$

Today the manner in which society in the U.S. dresses is very different than the early Israelites. Not only do people differ in the way they dress from ancient cultures, but also from each other, as can be seen in the clothing differences between people in the Middle East, Asia, or in the United States. Again, these laws were enacted for the purposes of distinguishing the people of God from their neighbors, who might have engaged in cross-dressing during

\footnotetext{
${ }^{45}$ Countryman, Dirt, Greed, and Sex, 30.

${ }^{46}$ Ibid., 39.

${ }^{47}$ Deuteronomy 14:21.

${ }^{48}$ Countryman, Dirt, Greed, and Sex, 59.
} 
pagan festivals. The passage can be seen as archaic in light of feminism which calls for equality of the sexes, but especially in light of queer theology which views gender presentation as an act of individual expression and is suspicious of gender roles that work to divide people into segregated categories of sex and gender with separately defined social roles.

\section{New Testament:}

\section{Romans 1:26-27}

${ }^{26}$ For this reason God gave them up to degrading passions. Their women exchanged natural intercourse for unnatural, ${ }^{27}$ and in the same way also the men, giving up natural intercourse with women, were consumed with passion for one another. Men committed shameless acts with men and received in their own persons the due penalty for their error.

Scholars have read these passages throughout the last two millennia in a myriad of ways. Some interpreters have put forth the idea that Paul "condemns bestiality or anal intercourse, and yet others that he condemns heterosexuals having homosexual experiences." ${ }^{49}$ Others glean from the texts that Paul explicitly prohibited same-sex relations, while others read this passage as Paul viewing (homo)sexuality as a "result of $\sin .{ }^{.50}$ Ambiguities presented in 1 Corinthians 6:9-10 are only confounded by Paul's theology in Romans 1:26-27.

\footnotetext{
${ }^{49}$ Bernadette J. Brooten, llove Between Women: Early Christian Responses to Female Homoeroticism, Chicago: University of Chicago Press, 1996, 192.

50 Ibid., 192.
} 
Bernadette J. Brooten, historian and author of Love Between Women: Early Christian Responses to Female Eroticism, offers distinct insight into Paul's theology by framing it intelligibly within Ancient Rome and alongside contemporary writings to better understand the cultural and political elements that influenced his letter to the Romans. According to Brooten, "this passage presents complex exegetical challenges" ${ }^{\mathrm{51}}$ of which many are still unresolved today. First, what is generally accepted is that Paul is speaking against idolatry, and relates in his letter what he has observed as examples of idolatrous behavior by the pagan gentiles.(1:7-23) Paul believed that the nature of God is revealed in God's good works; pagans or anyone else need not be preached the Gospel in order to know God. (1:19-20). Paul then makes the connection that because the gentiles know of the one God (without being preached the Gospel) they made a conscious decision to turn away from God and turn to paganism and pray and worship idols instead. Paul is referring to people who should know better, "even his eternal power and Godhead, so they are without excuse,"52 but still do not turn to the one true God but instead choose to worship idols.

Secondly, Paul understands homoerotic behavior as a result of idolatry (1:24). The pagans consciously turn away from the One God, and because of their idolatrous behavior God punished them with homoeroticism. For Brooten, Paul indeed condemns sexual relations between women, but in understanding Paul's theology, questions of natural theology and natural law can be answered.

${ }^{51}$ Brooten (216) presents in depth arguments on what is natural and unnatural intercourse within the context of gender/sexual hierarchies constructed and deemed "natural" in Paul's historic and cultural context. She presents a well-documented case for understanding Paul's audience.

${ }^{52}$ Romans 1:20. 
Comparing same-period authors, Brooten has teased out the societal categories of gender and sexuality. Rome classified all females as passive and subordinate. Free women were also higher in status than male or female slaves and lower in status than free men or women. Paul's understanding of women could be considered as traditional, but also a bit progressive; he called women men's vessels, but also worked side-by-side with women in various positions of the early churches. ${ }^{53}$ In whatever gender norms Paul viewed women, women today still do not fit Paul's gendered framework. He cannot be talking to women today, and most historians and theologians agree that Paul is not speaking about trans* people today that live outside of Paul's framework of gender. ${ }^{54}$ These differences in culture, between ancient and modern society, points to the distinct possibility that sexuality today does not fit Paul's framework of sexuality. Paul was not speaking about healthy queer relationships.

Paul describes to the Romans his observations of male homoerotic behavior and of the only act of female homoeroticism recounted in the entire Bible. He calls this behavior "unnatural", or para phusin, (1:26-27). The use of this phrase is puzzling for many theologians. Para phusin, beyond or against nature, is not explained in the Christian Bible. The inception of the phrase can be traced back to philosophic teachings of the Stoics, referring to anything excessive. Plutarch, the author and moralist, applied the term para phusin to

\footnotetext{
531 Corinthians 11:2-16; 14:33-36; 33-36; 1 Thessalonians 4:4.

${ }^{54}$ In an effort to include transgender, transsexual, transitioning, and gender non-conforming, gender-variant, or genderqueer people, an asterisk will be attached to the word trans as a standin for all marginalized genders or identities.
} 
diseases or fever, eating meat, and to the courage of women. ${ }^{55}$ It is also possible that Paul had in mind Jewish texts, whereby Jewish writers used the term para phusin to condemn pederasty, sexual relations between a man and a menstruating woman, and also of a man and a sterile woman. ${ }^{56}$

The best that can be done is to try to understand how the gender hierarchy of Paul's time affected the ethics on sexuality. Interestingly, the use of the word "exchanged," Brooten explains, "implies that [Paul believed] the women were capable of natural intercourse, just as those who "exchanged the glory of the immortal God for images" were capable of knowing and worshipping the true God." ${ }^{57}$ Today, for example, society might view an individual holding a high position of authority dating a subordinate with contempt (or disgust); in ancient Rome that arrangement was the norm of the day, while two men of the same status in (homo)sexual relations would normally be viewed with contempt (or disgust). For Brooten and other theologians, the social hierarchy both reflected and maintained a particular, culture-bound social order that is quite different than today. ${ }^{58}$

\footnotetext{
${ }^{55}$ Bernadette Brooten Love Between Women., 34.

${ }^{56}$ Ibid., 34.

${ }^{57}$ Ibid., 241
}

58 Jordan, in The Ethics of Sex 2002 works under the overarching theme that to understand the Bible, the culture in which it was produced needs to be understood;Herdt, Same Sex: Different Cultures 1997 also works under the same understanding of cultures. ;Foucault, The Order of Things: An Archaelogy of the Human Sciences 1970 is one of the foundational theorists that brought to light the need for different frameworks and understanding constructions when studying history. 
According to Brooten, the only time Paul mentions homoeroticism is in the letter to the Romans (1:26), but because of its "canonical status, Paul's condemnation of female and male homoeroticism enjoys a privileged and authoritative position not only within the church, but also, through its long-lasting influence, on the laws and culture of the Western world." ${ }^{\text {"59 }}$ Paul's theology includes the belief that individuals should know about the one God through acts of nature and without being preached the Gospel. Paul also clearly states that homoerotic behavior is a punishment, or as a result, for idolatrous behavior. The two components of Pauls' theology in I Romans, that people should know of the One true God through nature, and that homoeroticism is God's punishment for idolatrous behavior, has led to the condemnation of queer people. Christians today believe that people need to be preached the Gospel to know God, thus missionaries and evangelism. Also, people do not believe that God has punished people with homoerotic attraction due to idolatry. The two components that frame Pauline theology on homoerotic behavior are both widely discarded. Interestingly, his conclusion on homoerotic behavior is retained, while the arguments that led him to that conclusion have been abandoned.

\section{Corinthians 6:9-10}

9Do you not know that wrongdoers will not inherit the kingdom of God? Do not be deceived! Fornicators, idolaters, adulterers, male prostitutes, sodomites, ${ }^{10}$ thieves, the

\footnotetext{
${ }^{59}$ Brooten, Love Between Women,196. Most historical-critical biblical scholars are in consensus that Romans is one of the earliest writings and agree that Paul himself wrote it.
} 
greedy, drunkards, revilers, robbers-none of these will inherit the kingdom of God. ${ }^{60}$

I Corinthians 6:9-10 includes Paul's "vice list" of people who will not inherit the Kingdom of God (also found in 5:10-11). ${ }^{61}$ The use of the word "sodomite" above refers to what is today understood as "homosexual"; however, this was not how it was always understood, as will be shown. Paul lists the kinds of behaviors that will keep people from being admitted to the Kingdom of God. Although this is an ongoing debate, help in understanding this passage lies in the translation process. Boswell adds, "It is not readily apparent to modern English speakers with little knowledge of classical languages that the passage of thousands of years obscures, sometimes beyond recovery, the exact meaning of words in the languages of cultures with experiences and life-styles very different from their own." ${ }^{62}$ In this passage, Paul uses two words, malakoi and arsenokoitai. Table I lays out the different translations of these two words that have evolved since their appearance in the New Testament. ${ }^{63}$

\footnotetext{
${ }^{60}$ Italics mine.

${ }^{61}$ Rene A. Lopez,. "A Study of Pauline Passages with Vice List." Bibliotheca Sacra 168 (JulySept 2011): 301-316. Use of the phrase "vice list" taken from a six-part series published by Lopez, "The Pauline Vice Lists and Inheriting the Kingdom."

${ }^{62}$ Boswell, Christianity, Social Tolerance, and Homosexuality, 335.

${ }^{63}$ Charles D. Myers, Jr. "What the Bible Really Says About Homosexuality." Anima 1, no. 1 (1974): 21.
} 
Table I ${ }^{64}$

\begin{tabular}{|c|c|c|c|}
\hline Version & Year & Translation & Translation \\
\hline $\begin{array}{l}\text { Koine } \\
\text { Greek }\end{array}$ & $\begin{array}{l}56 \\
\text { A. D. }\end{array}$ & $\begin{array}{l}\text { malakoi } \\
1 \text { Corinthians } 6: 9-10\end{array}$ & \begin{tabular}{|l} 
arsenokoitai \\
1 Corinthians $6: 9-10$ \\
1 Timothy $1: 10$
\end{tabular} \\
\hline \begin{tabular}{|l} 
Latin \\
Vulgate
\end{tabular} & 405 & molles & $\begin{array}{l}\text { masculorum } \\
\text { concubitores }\end{array}$ \\
\hline Wyclif & 1508 & lecchouris & synne of Sodom \\
\hline Tyndale & 1525 & weaklings & $\begin{array}{l}\text { abusers of themselves } \\
\text { with mankynde }\end{array}$ \\
\hline \begin{tabular}{|l} 
Bishops \\
Bible
\end{tabular} & 1568 & effeminate & liers with mankinde \\
\hline $\begin{array}{l}\text { King James } \\
\text { Authorized } \\
\text { Version }\end{array}$ & 1611 & effeminate & $\begin{array}{l}\text { abusers of themselves } \\
\text { with mankind }\end{array}$ \\
\hline Darby & 1890 & $\begin{array}{l}\text { those who make women } \\
\text { of themselves }\end{array}$ & $\begin{array}{l}\text { abuse themselves } \\
\text { with men }\end{array}$ \\
\hline \begin{tabular}{|l|} 
American \\
Standard \\
Version \\
\end{tabular} & 1901 & effeminate & $\begin{array}{l}\text { abusers of themselves } \\
\text { with men }\end{array}$ \\
\hline \begin{tabular}{|l|} 
Wesley's \\
New \\
Testament \\
\end{tabular} & 1938 & guilty of unnatural crime & \\
\hline \begin{tabular}{|l} 
Revised \\
Standard \\
Version \\
\end{tabular} & 1946 & $\begin{array}{l}\text { homosexual-1st use of word } \\
\text { homosexual in the Holy } \\
\text { Bible. }\end{array}$ & \\
\hline $\begin{array}{l}\text { New } \\
\text { American } \\
\text { Catholic }\end{array}$ & 1970 & homosexual perverts & \\
\hline \begin{tabular}{|l|} 
Revised \\
Standard \\
Version \\
\end{tabular} & 1971 & sexual perverts & child molesters \\
\hline $\begin{array}{l}\text { New King } \\
\text { James }\end{array}$ & 1979 & homosexuals & \\
\hline $\begin{array}{l}\text { New } \\
\text { American }\end{array}$ & 1987 & boy prostitutes & homosexual offenders \\
\hline
\end{tabular}

${ }^{64}$ Jeramy Townsley, Translations of "Malakoi" and "Arsenokoitai" Through History, http://christiangays.com/articles/malakoi.shtml 2000 (accessed February 19, 2013. 


\begin{tabular}{|c|c|c|c|}
\hline Catholic & & & \\
\hline $\begin{array}{l}\text { New } \\
\text { Revised } \\
\text { Standard }\end{array}$ & 1989 & male prostitutes & sodomites \\
\hline $\begin{array}{l}\text { New Living } \\
\text { Translation }\end{array}$ & 1996 & male prostitutes & practicing homosexuals \\
\hline $\begin{array}{l}\text { Third } \\
\text { Millennium } \\
\text { Bible }\end{array}$ & 1998 & effeminate & sodomites \\
\hline
\end{tabular}

Table I shows that Bible translations of both malakoi and arsenokoitoi vary greatly. Some of these translations allude to idolatry, to sexual immorality of various kinds, and to (homo)sexuality as we know it today, although this is clearly a novel insertion into the Bible as the word does not exist in Hebrew or Greek. In The Church and the Homosexual, John J. McNeil writes, ""The variation in translations points to the fact that there is very little understanding of the precise meaning of Paul's terms", adding, "Translations appear at times to be based on preconceptions rather than serious scholarship." ${ }^{165}$

The word malakoi was common at the time, appearing in patristic writings and other places in the NT, meaning "soft". Contemporary colloquialisms would interpret a "soft" male today as derogatorily effeminate; however, at the time malakoi referred to varied terms such as "cowardly, refined, weak-willed, delicate, gentle, and debauched....in a specifically moral context it very frequently meant licentious, loose, or wanting in self-control" ${ }^{66}$ Arsenokoitoi has a similar history, but is further confounded by the fact that Paul coined the term instead of

\footnotetext{
65 John J. McNeil, The Church and the Homosexual (Mass: Beacon Press, 1993), 51.

${ }^{66}$ Boswell, Christianity, Social Tolerance, and Homosexuality 106.
} 
using the many Greek terms available at the time for male-male relations in ancient Greek. ${ }^{67}$ In 1946 the word "homosexual" was added to the Bible instead of other previous translations for arsenokoitoi. Many people are outraged when they learn that even though the word 'homosexual' was not understood in ancient times nor did Hebrew or Greek have such a word, it was still be inserted arbitrarily into the Bible. The insertion of this translation has then served to validate and justify homophobia.

\section{Timothy 1:9-10}

${ }^{9}$ This means understanding that the law is laid down not for the innocent but for the lawless and disobedient, for the godless and sinful, for the unholy and profane, for those who kill their father or mother, for murderers, ${ }^{10}$ fornicators, sodomites, slave traders, liars, perjurers, and whatever else is contrary to the sound teaching. ${ }^{68}$

The final passage to be analyzed is 1 Timothy, but as we have seen, the idea that ties the story of Sodom against (homo)sexuality is based on the belief that all of the men of the town attempted to rape male angels. Although there are various passages in the Bible that state the lists of Sodom's wicked deeds, none of them point to (homo)sexuality. Sodom's destruction by God was the result of a violation of hospitality, pride, and insensitivity to the needs of the poor. ${ }^{69}$ Again,

\footnotetext{
67 Jordan, Ethics of Sex, 28.

${ }^{68}$ Italics mine.

69 Isaiah 3:8-9; Jeremiah 23:14; Ezekiel 16:49-50; Matt 11:23;

http://www.iwgonline.org/docs/sodom.html cites classical Jewish Texts that support the argument that Sodom and Gomorrah were not destroyed due to homosexuality.
} 
the use of the word sodomite in this passage is skewed to refer to homosexuals. "No Extant text or manuscript, Hebrew Greek, Syriac, or Aramaic, contains such a word...Neither Hebrew nor Arabic has such a word today, nor does modern Greek."${ }^{170}$

Mistranslation is common, especially when a) texts are translated from one language into multiple languages and $b$ ) when sexual and ethical norms of the dominant culture prevail and are then used as a framework for interpretations of ancient cultures. It is now becoming more and more common for scholars and theologians agree that this passage has nothing to do with (homo)sexuality, or homoerotic acts. ${ }^{71}$

Some scholars have concluded that since the Sodom narrative and the Holiness Code are both included in the Torah, the audience must have been aware of (homo)sexual people and would draw the connection from Leviticus to Sodom. However, Countryman points out that the Torah "itself does not treat the purity code of Leviticus as existing in Lot's time and since the code never applied to Gentiles in general it is not clear that purity is relevant to the interpretation of the Sodom story. ${ }^{72}$ The passage in I Timothy does not contain any language that pertains to queer people. In fact, Jesus himself believed that the city was

\footnotetext{
${ }^{70}$ Boswell, Christianity, Social Tolerance, and Homosexuality, 92.

${ }^{71}$ Derrick Sherwin Bailey, Homosexuality and the Western Christian Tradition Needs (City: Publisher,1975); Boswell, Christianity, Social Tolerance ; Jordan, Silence of Sodom.2000;and Brooten, Love Between Women.

${ }^{72}$ Countryman,Dirt, Greed, and Sex, 31.
} 
destroyed because of inhospitality. ${ }^{73}$ "Sodomite" in this passage refers to the sins committed by the people of Sodom, which does not have to do with homoeroticism. Queer people can also be inhospitable, prideful, and insensitive; they can also be rapists, and murderers, but is the behavior of homoeroticism itself a $\sin$ ? As one ethicist stated, "The story of Sodom and Gomorrah does not provide scriptural support for such a conclusion., ${ }^{74}$

\section{Sexual Dimorphism in Genesis}

Sexual dimorphism (in short) is the separations of species according to their observable traits, humans, therefore, are separated into only two categories, male and female. ${ }^{75}$ Most churches in the U.S. routinely use the clobber passages to condone queer people's exclusion from the sacraments and although the Genesis stories of Creation are not generally used as clobber passages, they are usually referenced to assert God's intention of creating the separate categories of male and female, which undermines and silences the experience of trans* people. ${ }^{76}$ In the past, Genesis 2:18 was quoted to affirm the "natural" hierarchal positions that God intended when Eve was created as a "helper" for Adam (2:18).

\footnotetext{
${ }^{73}$ Matthew 10:14; Luke 10:10-12

${ }^{74}$ Jung, Patricia Beattie; Smith, Ralph F., Heterosexism: An Ethical Challenge (NY: University of NY Press) 1993, 70.

${ }^{75}$ Brittanica Online 2011 "Sexual Dimorphism," http://www.britannica.com/EBchecked/topic/537133/sexual-dimorphism (accessed January, 23, 2013).

${ }^{76}$ Genesis offers two creation stories. The first, Genesis 1:25-27, God makes all the animals and then makes "man and woman" simultaneously (this is considered chronologically older). The second, Genesis 2:18-22, God makes Adam first, then the animals, and then Eve as a "helper." The latter is considered in Christian interpretation as the later addition into the sacred texts.
} 
The patriarchal interpretation has since been understood as culture-bound, and in the U.S. most people favor an egalitarian political, economic, and social way of life. Feminists still quote Genesis 1:25-27 to support egalitarianism in religious life. The chronologically first written story describes the creation of Eve and Adam as simultaneously, after the creation of the animals (instead of as rulers over the animals to be created). Still, when quoting either Creation stories, most people do not include the experience of transgender/transsexual (trans*) people as part of the Adam and Eve creation of gender, nor see them as also being intentionally and perfectly created in God's image. The refusal to see how sexual dimorphism is the root of patriarchy has been the breeding ground for various other intersections of oppressions, including homophobia, heterosexism, heteropatriarchy, and cis-hetero-patriarchy. ${ }^{77}$ My thesis argues that sexual dimorphism in both Creation stories is used to perpetuate the notion that sex and gender are God-given categories, instead of social constructions rooted in culture that can and do change according to every society's social norms.

In keeping with certain staples of queer theory, queer theologians may also incorporate presuppositions of sexual dimorphism, such as in the work of queer theorists, historians, anthropologists, and others. Judith Butler, a queer theorist who believes in destabilizing the concept of gender, in her famous work

\footnotetext{
${ }^{77}$ Cis-hetero-patriarchy is difficult to define because of its novelty and lack of mainstream use. Cisgender, a new and controversial term, refers to people whose sex assignment at birth (male / female) aligns with the way the person identifies, expresses, and presents their gender (masculinity / femininity). Heterosexual is a person whose sexual preferences include oppositesex attractions exclusively. Patriarchy is the intersection of sexism, misogynism, and male domination. Thus, cis-hetero-patriarchy is the arrangement of social order privileging cisgender, heterosexual males.
} 
Gender Trouble illustrates how categories of "woman", "man", and "lesbian" work to restrict the broadening and development of gender. ${ }^{78}$ These labels restrict and confine gender instead of working towards the continuous expansion or deconstruction of gender "roles", or towards an understanding of gender as a continuum and as fluid, instead of progressing in linear fashion.

Foucault, arguably the Father of queer theory, also feeds Butler's work through his works on "subjugated knowledges" which convey the ways in which everyday experiences have been silenced, and demonstrates how this is caused by the systemization of power, which for Butler's purpose results in sexual dimorphism and regulated gender norms. My thesis builds on the work of Foucault and Butler, and is produced within the understanding that sexual dimorphism is the foundation for many forms of oppression which have birthed discriminatory practices in secular and religious spaces. Against many modern arguments and much political thought, separating humans by assigned sex at the time of their birth on the basis of the presence or absence of a penis is no longer a functional paradigm as the foundation of gender and sexuality-- or at least it is not one that will function successfully for much longer. ${ }^{79}$ Sexual dimorphism has been and continues to be supported, institutionalized, and reinforced through appeals to scripture, ignoring and silencing the many faithful voices and the

\footnotetext{
${ }^{78}$ Butler, Gender Trouble: Feminism and the Subversion of Identity (NY:Routledge, 1990).

${ }^{79}$ Within my personal understanding, sex is also socially constructed as a binary system with dual poles defining male and female identities. Within my personal understanding of gender construction, sex is subsumed under gender, and gender identity is placed within a continuum; being made up of various components, race, status, socioeconomic status, among others, but sex assignment is a primary component to gender identity construction. For simplification purposes, "sexual" dimorphism will be used here instead of "gender" dimorphism.
} 
multiplicity of experiences that vary from the dominant culture. In particular, the Genesis stories of Creation are employed to assert and affirm sexual dimorphism.

The sexual dichotomy is not a Christian or Jewish invention, but both religions understood the sexes as being divided "naturally" and that these different sexes produced gender (masculinity/femininity); gender roles then derived "naturally" from the binary. ${ }^{80}$ Genesis 1:1-23 and Genesis 2:18-25 are often quoted to reinforce sexual dimorphism as God-given instead of culturebound and to reject the idea of a sexual continuum. ${ }^{81}$

Supporters of the sexual dichotomy have found validation for their claims in the Genesis stories of creation. "Therefore a man leaves his father and his mother and clings to his wife, and they become one flesh." (2:24) The passage has been used to support the view that God intends only two opposite-sex individuals in sexual relationships within marriage, with a male authority figure, even though in the nascent faith of Christianity the sexes were not differentiated, as seen when Paul erases difference between the sexes in Galatians. ${ }^{82}$ The theme was thus replicated and reinforced throughout the Bible where males and females were distinguished by sex with separate gender roles, prescribed "in

\footnotetext{
${ }^{80}$ Christine E. Gudorf, "Sexual Dimorphism: Challenges to Religion and Religious Ethics" American Academy of Religion 2001, (69)4, 867.

${ }^{81}$ A continuum implies that fixed or static identities in a strict binary do not exist, rather identities fall along a continuum that 1 ) indicates fluid identity, and 2) understands that hierarchal positioning (as non-hierarchal positioning) only exist as constructs.

${ }^{82}$ Galatians 3:28
} 
terms of social function, worth, and relation to each other and to God." ${ }^{83}$ As a consequence of sexual dimorphism and strict gender norms "by the second century, leadership in Christianity came to increasingly require maleness" (I Timothy 3:-17). ${ }^{84}$

Mark D. Futato would say that, "The question is not, ought one to begin in Genesis 1 or Genesis 2?. The question is, what is the interpretation that does most justice to both texts?"85 The creation stories, both the newer and older story, are routinely used against people that fall outside of a constructed system of gender. The gender binary paradigm, as presented by mainstream Christians, is that the creation story does not allow room for gender-variant people because it is clear to them that God created only male and female: Adam and Eve.

In response to Futato, the best way to interpret a text would be to ask if it does justice to its people. Are the interpretations of the stories of creation doing justice to Intersex and genderqueer people that do not fall within the constructed male/female binary? It is clear that the male/female dichotomy in the creation Stories of the Old Testament (OT) may be interpreted through a context of both power and hierarchy, as well as cultural norms of the time that more or less kept society in order. When taken literally that there are only two sexes, male and female, it would mean that God did not create intersex individuals.

\footnotetext{
${ }^{83}$ Ibid., 868.

84 Ibid., 868.

${ }^{85}$ Mark D. Futato "Because it Had Rained", Westminster Theological Journal 60 (1998) 1-21.
} 
Once termed 'hermaphrodites', the Intersex Society of North America has listed over 15 conditions that result in intersex individuals, stating that 1 in every 1500-2000 births is intersex..$^{86}$ If God's works are perfect and God does not create mistakes, then surely the Word is also for intersex people. ${ }^{87}$ While the Catholic church does have a firm stance on (homo)sexuality, it does not have a concrete stance on intersex people. Most exclusionary Protestant churches also do not have a firm stance on intersex people. Transgender identity is still being discussed in religious circles. Very much like intersex individuals, trans* ${ }^{*}$ people do not neatly fall within a male/female sexual dichotomy. How does the church reconcile intersex and transgender individuals with present Church teachings? They do not. The Roman Catholic Church in particular has stayed silent, in particular about Intersex people and therefore tacitly allows society and individual churches to discriminate against gender non-conforming people in every aspect of life, secular as well as religious. ${ }^{88}$

Medical science and technology have shown that gender identity is found along a continuum, rather than fall into a dichotomy. ${ }^{89}$ Thus, the male/female binary that is prescribed throughout the Bible can be analyzed in its culturalhistorical context, as well as within a framework of limited knowledge of human biology. In this way, much as many minds have been changed towards slavery

\footnotetext{
${ }^{86}$ Intersex Society of North America

${ }^{87}$ Deuteronomy 32:4; Psalms 18:30; Matthew 5:48; Romans 12:2

${ }^{88}$ The Vatican's stance on "sex-change" operations will be presented later; however, I could not find any official stance on Intersex people by the Vatican.

${ }^{89}$ Kinsey reports 1946; ISNA 2008
} 
and sexism, discrimination, fear, and lack of understanding does not need to continue to exclude LGBTIQ individuals from church life. Instead, intersex as well as gender non-conforming individuals can be accepted for and understood as also created in the image of God. At a time in the United States when there are hundreds of thousands of people who biologically defy the categories of male and female and refute the binary from birth it is counterintuitive for religions to continue to push sexual dimorphism as "natural."

Ecclesial authorities have appropriated the Bible and Biblical "truth" is produced and controlled by these authorities that are predominantly cisgender, heterosexual, men. Modern queer scholarship has challenged many Biblical teachings and literalist interpretations of the Bible and queer people have started to read their own liberation in the same passages as other previously oppressed groups. As Dr. Christine E. Gudorf states in "The Erosion of Sexual Dimorphism," not only does the erosion of sexual dimorphism challenge traditional religious teachings, but it also challenges the "moral authority of religions, most directly the moral authority of their teaching on sexual behavior".$^{90}$ The Bible is no longer the privileged possession of an elite group, or belonging to fundamentalists, mainstream churches, or the Roman Catholic Church. Queer Christians understand that they must reject the traditional interpretations of the Bible, along with heteropatriarchal and homophobic constructions to depoliticize the text. By re-constructing the stories of Genesis in ways that do not dichotomize sex or

${ }^{90}$ Gudorf, E. Christine, The Erosion of Sexual Dimorphism 871. 
gender, queer people understand Christian theology in radically different ways than their patriarchal, or feminist, predecessors. "Queer theology" calls for a reexamination and redefinition of the Bible narratives through a framework that understands gender and sexuality as social constructions. ${ }^{91}$

In Queering Genesis: "Male and Female (and others) He Created Them" ${ }^{92}$ Terrence, a blogger with a website dedicated to matters relating to the religious oppression of queer people, offers an exceptional queer exegesis of the Genesis Creation Story. The premise of this blog is that the sexual categories of male and female are constructed by culture and society, from the social construct a strict dichotomy of gender has been promoted by homophobic and heterosexist interpretations of Genesis. In it Terrance offers a short explanation of each day of Creation, beginning with the creation of day and night:

On the first day, "God separated the light from the darkness. God called the light Day, and the darkness night." Does this imply that there is nothing in between? Of course not. There is twilight, there is gloaming. Night can be well lit by a full moon, day can be dull and cloudy. But still, there is night and day, darkness and light - which do not deny the existence of intermediate states.

On the third day, God separated the land from the waters. "God called the dry land Earth, and the waters he called Seas." Again, we know from simple observation that this simplifies the picture. On the land there are also rivers and

\footnotetext{
${ }^{91}$ Gilbert Herdt, Third Sex Third Gender: Beyond Sexual Dimorphism in Culture and History NY: Zone Books, 1996, 39.

92 Terrence (blogger), 2011, Queering Genesis: Male and Female (and others) He Created Them, http://myqueerscripture.blogspot.com/2011/04/queering-genesis-and-female-and-others.html (accessed March 05, 2013).
} 
lakes, as well as marshes, swamps and deltas that are not clearly either wet or dry, or may vary in state with the seasons. At the coast, there are intertidal zones, which are land at low tide, and sea at high. On the oceans, there are arctic zones where frozen sea creates ice shelves, a form of "dry" land. Yet none of this negates the concept of a difference between dry land and sea - and the use of the concept does not deny the existence of intermediate states.

Terrence concludes:

To take "male and female" as restricting all understanding of sex, gender and orientation to just the single model described is no more valid than denying the existence of rivers, estuaries and marshes because only the Earth and Seas are named to represent dry land and water, or to deny the planets, comets and galaxies because only the sun, moon and stars are explicitly named. Read in its entirety, as an expressive and powerful passage of literature rather than a scientific catalogue, this is a celebration of the diversity of creation. This includes the diversity of biological sex, gender and orientation that we as the queer community embody - and all are made "in the image of God".

The exegesis presented by Terrence offers a deconstruction of several binaries offered in the creation narrative that are generally and widely understood to be a simplification of Creation. In this way Terrence frames the logic of the male/female binary as equally inadequate or as a simplification of the diversity of gender and sexuality. In conclusion, the contemporary circumstances of inequality and social injustices that surround the queer community and that pervades religious traditions fuels the need for modern queer theological scholarship. This scholarship, in turn, reflects queer scholarship in linguistics, historical analyses, biology, psychology and other sciences. Therefore, Terrence's queer theology is shaped and influenced by, not only traditional 
interpretations, but by a myriad of other disciplines that work to challenge archaic notions of culture and society. 


\section{An Explanation of The Eucharist}

The Eucharist allows the body of believers to participate in the shared meal, Jesus' primary arena for instruction and fellowship with the congregation. According to Scripture, Jesus was not only often invited to share private meals with friends, poor people, ill-reputed officials and tax collectors, as well as larger public gatherings, but he also hosted many inclusive meals at his home in Capernaum. The inclusiveness of these meals was an important part of Jesus' teaching. For instance, Jesus ate with Matthew in the company of tax collectors and other people of ill repute, defying the classist notions of the day.$^{93}$ In Luke you can also find Jesus, at a banquet, fellowshipping with the sick and the ostracized. ${ }^{94}$ Luke chronicles Jesus' transforming the communal meal into a place of forgiveness, empowerment and community through fellowship. In the account of the meal at the home of Martha and Mary, Jesus attacks the stereotypical role for a woman at that time, in condoning and affirming Mary's desire to be taught, as opposed to agreeing with Martha's assertion that Mary's place was in the kitchen. ${ }^{95}$ With one woman at his feet, and the other preparing food, he affirmed the actions of the student at his feet, a place traditionally reserved for men. The passage is a clear statement of subversion of gender roles. These few examples demonstrate that these times of gathering in fellowship were meant to be more than just a means to satisfy the physical

\footnotetext{
${ }^{93}$ Luke 5:29

${ }^{94}$ Luke 7:36-50

${ }^{95}$ Luke 10:38-42
} 
appetite. Thus, the communal meal is transformed by the very attendance of the guests and Christian culture enshrines the meal as a place of unity, forgiveness, healing, teaching, and love.

The best-remembered meal is the Last Supper, recorded in three of the four gospels, after which Communion is modeled. Jesus and his disciples gathered for the Seder, or Passover meal, in which Jews celebrate the Exodus and the Israelites' liberation from slavery. ${ }^{96}$ Jesus broke bread with his disciples during his last ritual feast before his crucifixion, telling them that the bread he gave them was his body, and the wine his blood. Jesus instructed his disciples to eat and drink and "do this...in remembrance of me." ${ }^{97}$ Below is a reconstruction of the Last Supper by Paul in a letter to the Corinthians.

\section{Corinthians 11:24-26}

24 and when he had given thanks, he broke it and said, "This is my body that is for you. Do this in remembrance of me." 25 In the same way he took the cup also, after supper, saying, "This cup is the new covenant in my blood. Do this, as often as you drink it, in remembrance of me." 26 For as often as you eat this bread and drink the cup, you proclaim the Lord's death until he comes.

In this passage, Paul explains that the last meal Jesus shared and the last words Jesus spoke was a special meal and since then this meal has been sacramentalized, or consecrated, into a ritual with many names: The Breaking of

\footnotetext{
96 The notion of the Seder meal as the last meal Jesus shared is generally believed although is still being debated.

${ }^{97}$ Also found in Luke 22:19.
} 
Bread, Holy Communion, the Lord's Supper, and the Eucharist. ${ }^{98}$ The term Eucharist derives from the Greek word eucharista, which has been translated as "thanksgiving", the term Communion derives from the early Christians. Just shortly before the passage above, Paul said "the cup of blessing that we bless, is it not a koinonia in the blood of Christ?" (10:16). Koinonia is translated as "communion", "sharing" and also "fellowship". ${ }^{99}$ The bread symbolizes the body of Jesus, the wine his blood. Through Jesus a Christian is nourished spiritually, sharing in his body and blood.

The belief that is at the core of this ritual is what John says in 1:14, "The Word is made flesh and dwells among us, full of grace and truth." While my thesis does not go into the four accounts in the Gospels, it is sufficient to say that in the sacrament of Communion Jesus offers his own body, his flesh, so that God is in Jesus and then Jesus is in us. The bread and wine, through the sacrament, unites the receiver with God and Jesus. Indeed, the Eucharist is the continuation of the Incarnation, of when God became human, took form, walked in the flesh. Through the elements Jesus takes the flesh again. It can also be understood that God bestows gifts upon the body, and that the body of the receiver is what receives mercy and grace through the body and blood of Jesus. During

\footnotetext{
${ }^{98}$ Each of these names involve a specific interpretation of the practice, but for ecumenical reasons each of these names will be used, keeping in mind that when speaking in reference to "churches" or "exclusionary churches" Communion will be used with more frequency. Eucharist will be used for Episcopalians, Roman Catholic, and United Methodist that use Lord's Supper, Holy Communion, or Eucharist.

${ }^{99}$ Melva Wilston Costen, What do Presbyterians believe about Communion? http://www.presbyterianmission.org/ministries/today/sacraments/ (accessed January 23, 2013).
} 
Eucharist, the body of God is in Jesus, the body of Jesus is in us, and our bodies are what take in these gifts.

\section{Corinthians 11:27-29}

27 Whoever, therefore, eats the bread or drinks the cup of the Lord in an unworthy manner will be answerable for the body and blood of the Lord. 28 Examine yourselves, and only then eat of the bread and drink of the cup. 29 For all who eat and drink without discerning the body, eat and drink judgment against themselves.

In this passage Paul recounts the Last Supper and the last words of Jesus, but adds commentary that have created two millenia worth of debates, arguments, and points of views concerning this very passage. In passages 2729 Paul includes a piece that implies that there is a qualifier, a requirement to be fulfilled, for the individual to "do this in remembrance of me" and to not "eat and drink judgment against" yourself, a requirement not found in the gospel accounts of this meal. The exact requirement is exactly the area of contention that has not been resolved. There have been rich theological discussions that have stemmed from a millieu of perspectives, from the Reformation to the present. The resultant liturgy differs per tradition and includes qualifiers that separate and categorize people according to who can participate and those that are "unworthy" as is shown in Table II (page 52). 


\section{Importance of Communion}

The Archdiocese of Minnesota tells users on their website to "notice that this is a communal experience. Receiving the Eucharist is not just about me and Jesus; it is us and Jesus. I like the double meanings of both the terms "body of Christ" and "Communion" — they both simultaneously refer to the Eucharist and the Church.." ${ }^{100}$ The doctrine of the Roman Catholic Church is that of transubstantiation, which is the changing of the bread and wine into the actual body and blood of Christ at the time of consecration. To take part of this very holy ritual one must be "in a state of grace." Protestants, on the other hand, reject the idea of transubstantiation. Some Lutherans believe in consubstantiation, where the substance of body and blood of Jesus are present alongside the wafer and wine. Episcopalians are divided and the theology differs. Some believe in transubstantiation, others believe in consubstantiation, and still others believe something similar to consubstantiation, which is, the substance of Jesus stays consecrated within the elements even after mass. Lutherans do not believe in the latter. Baptists, on the other hand, find the elements symbolic, and believe Jesus was meant for us to do this, literally, in "remembrance". For Presbyterians, the sacraments are a "testimony of God's favor toward the church, confirmed by an outward sign, with a mutual testifying of our godliness toward God. It is a primal, physical act that signifies a spiritual relationship between personal beings."101 They also believe that the receiving of the elements is symbolic, for the sole

\footnotetext{
${ }^{100}$ Rev. Thomas Margevicius, The Mass - Part 5: What happens during the Communion rite?,, 2011, http://rediscover.archspm.org/belonging/topic.php?id=7246 (accessed January, 02, 2013.

${ }^{101}$ Costen 2013, http://www.presbyterianmission.org/ministries/today/sacraments/
} 
purpose to remember to live a committed life. Presbyterians do not believe that there should be any prerequisites before taking Communion because they "cannot wait until they are worthy" and "worthiness is found in putting our trust in God." ${ }^{102}$

The wafer, or bread, is nourishment for the spirit as well as for the body. The taking of Communion is a direct connection to the mystery of the faith, in which Christians can be a part of the miracles that Jesus performed on Earth. From whatever Christian tradition an individual comes, they believe that something happens during Communion, even if it is as simple as church fellowship, for some. Transformation is a dominant theme that people relate to, because of the transformation of the bread into the body of Christ, and the wine into the blood of Christ. When there are too many mouths to feed and not enough food, the Eucharist is there to reconcile one's hunger with justice, a justice that does not only feed the body but also eradicates hunger from the soul. The transformational abilities of the ritual, therefore, are innumerable. It is understandable that in spite of all the hostility and inhospitality from exclusive churches queer people of faith might interpret Communion to symbolize transformation and justice in unconventional, or queer, ways. Beginning in the $16^{\text {th }}$ century the issue of Christ's presence was debated between Catholics and Protestants, becoming one of the most problematic points of contention between the two traditions. ${ }^{103}$ Since then the Churches have developed particular liturgies

102 Ibid., same webpage. 
when it comes to Eucharist or Communion, with nuanced differences that have become embedded in the tradition of each church.

In spite of liturgical differences, the ritual is fundamental to the faith because of the qualities of renewal, hope, and transformation it possesses. Jesus's birth, death, and resurrection are all contained within the elements. The story continues to touch us personally during the sacrament. It involves our story, too, because the message renews us, the ritual promises hope, and the transformation works, after receiving the elements, from within by uniting the receiver with God and church. It is crucial to understand that during "communion" it is only in the people that the relationship between God and community is fulfilled. Jesus sat at a table with the marginalized, oppressed, and socially disliked and ate with them, taught them, talked to them, and yes, even touched them. The communal feast is the nature of this sacrament, where individuals gather around a table to be nourished bodily, as well as spiritually.

\footnotetext{
${ }^{103}$ Tony Maan," The eucharistic presence of Christ in SEventeenth Century Dutch Protestant Popular piety: toward a catholic-protestant rapprochement?" Journal of Ecumenical Studies, (43) 4, 2008.
} 


\section{Who is Worthy?}

As many mainstream Protestant churches as there are, there are that many differences in liturgies for Communion, beginning with the actual name (whether Communion, the Lord's Supper, Eucharist) and branching out differently from one another in respect to different adherences of liturgy. They have, however, since the Reformation come to agreement on one new issue that is now becoming as far-reaching and as divisive as the Reformation debates over the presence of Christ in the elements: that homosexuals cannot participate in the Eucharist. ${ }^{104}$ The Roman Catholic Church offers "communion for those that are in a state of grace", or in other words, only for those (ascribed here) as "worthy". ${ }^{105}$ Most mainline Protestant churches, while they do not have as extensive a criterion for eligibility as that of Catholics, do object to the participation of queer people. Table II gives an overview of church stances on participant eligibility.

\footnotetext{
104 "Mainstream Protestant churches" here refer to the Evangelical Lutheran Church of America (ELCA), the Presbyterian Church, United Methodist Church, and the American Baptist Churches $(A B C)$, and a variety of other Protestant denominations that have exclusionary policies or practices.

${ }^{105}$ Didache, an early Christian document written around A.D. 70, states: "Whosoever is holy [i.e., in a state of sanctifying grace], let him approach. Whosoever is not, let him repent" Peter Kirby Didache, 2012 http://www.earlychristianwritings.com/didache.html (accessed November 12, 2012).
} 
Table II

\begin{tabular}{|l|l|}
\hline Church: $^{106}$ & Who may take communion ${ }^{101}$ \\
\hline $\begin{array}{l}\text { Evangelical Lutheran } \\
\text { Church of America } \\
\text { (ECLA) }\end{array}$ & $\begin{array}{l}\text { All people can take communion; particular churches } \\
\text { may push for baptism requisite. }\end{array}$ \\
\hline Presbyterian Church & All people may take communion. ${ }^{109}$ \\
\hline United Methodist Church & $\begin{array}{l}\text { All people may take communion, except for LGBTQ } \\
\text { people. }{ }^{110}\end{array}$ \\
\hline Episcopal Church & All people may take communion. ${ }^{111}$ \\
\hline American Baptist & $\begin{array}{l}\text { Baptism required. LGBTQ people cannot take } \\
\text { communion. }{ }^{112}\end{array}$ \\
Churches & \\
\hline
\end{tabular}

106 Pentecostals have a rich history of anti-gay activism, both in South America as well as rumored in Uganda to be associated with the "kill the gays" bill. Because of the political investments that both Pentecostals and Mormons have made for anti-gay propaganda and legislation, neither are analyzed in this thesis since they are seen as outside of the mainline churches and go above and beyond exclusionary practices.

${ }^{107}$ Although it may seem as though only 3 out of 6 denominations exclude queer people, Catholics, Methodists, and Baptists make up the majority of Christian members in the U.S. Their numbers in membership easily outweigh the numbers of members in "open and affirming" congregations. http://religions.pewforum.org/reports

${ }^{108}$ Chris Duckworth, A Pastor's Approach to Holy Communion (Lutheran), 2012, http://www.livinglutheran.com/seeds/a-pastors-approach-to-holy-communion.html\#.UMNfSOe8aC (accessed November 21, 2012); Michael Rhinehart, Compassion and Understanding,2012, http://www.livinglutheran.com/blog/2010/10/compassion-andunderstanding-1.html\#.UMNeb-Oe8aA (accessed November 21, 2012).

${ }^{109}$ David Maxwell, Gays Okay in the PC(USA), 2011, http://blog.thethoughtfulchristian.com/2011/05/gays-okay-in-the-pcusa.html (accessed November 23, 2012).

110 "Homosexuality is incompatible with Christian Teaching" as stated on United Methodist Church mission. http://archives.umc.org/interior.asp?mid=1324 (accessed November 21, 2012).

${ }^{111}$ Katherine Jefferts Schori, Episcopal Church Presiding Bishop Katharine Jefferts Schori concerning proposed bill in Uganda 2012 http://www.episcopalchurch.org/notice/episcopalchurch-presiding-bishop-katharine-jefferts-schori-concerning-proposed-bill-uganda (accessed November 20, 2012).

112 American Baptist Churches USA n.d. Policy Statements and Resolutions, http://www.abcusa.org/wp-content/uploads/2012/06/homosexuality.pdf (accessed November 21, 2012). 


\begin{tabular}{|l|l|}
\hline$*$ Roman Catholic & $\begin{array}{l}\text { 1.Must not be in a state of mortal sin (homosexuals } \\
\text { are explicitly listed in this list) } \\
\text { 2. Must have attended confession since last mortal } \\
\text { sin. } \\
\text { 3. Must believe in transubstantiation. } \\
\text { 4. Must not be under ecclesiastical censure. }\end{array}$ \\
\hline
\end{tabular}

- Some present-day extreme arguments within the Catholic Church call for the exclusion from Eucharist not only of Roman Catholics that run afoul of these four requirements, but also of those who sympathize or align themselves with pro-equality views. ${ }^{114}$

There are divergent views between churches on the call for inclusion from queer people. ${ }^{115}$ When churches exclude people from participating in the Communion sacrament and deny them a place at the table on the basis of sexual orientation and gender identity, they find their support in the clobber passages. ${ }^{116}$ The arguments for exclusion vary very little on the subject of queer people participating in Communion, or Eucharist.

The Roman Catholic Church has a list (see Chart B) on who is worthy to receive the sacrament, with another policy on what constitutes a mortal sin, and of course also on confession, and another requirement for Eucharist. In fact,

\footnotetext{
${ }^{113}$ Protestants and/or non-Catholics are also not allowed to partake of Eucharist in Roman Catholicism.

114 John-Henry Weston, New Jersey Archbishop Myers: Catholics who back gay 'marriage' should not receive Holy Communion, Lifesite News 9/27/2012, http://newyork.cbslocal.com/2012/09/25/newark-archbishop-catholics-who-support-gay-marriageshould-not-receive-holy-communion/ (accessed November 20, 2012).

${ }^{115}$ Ralph G. Wilburn, “A Theology of the Sacraments”, Mid-Stream, 1966(5)2, 11.

${ }^{116}$ Porter, Stanley E; Evans, Craig A., "Vice and Virtues List", Dictionary of New Testament Background : A Compendium of Contemporary Biblical Scholarship, 2000, 32.
} 
Catholic bloggers seem pretty educated on the subject. A blogger posted, "A person with homosexual tendencies, who is Catholic can of course receive Holy Communion, but not if they are acting on such and living in a way contrary to the Faith. Just like others who live in objectively gravely sinful situations (like girlfriends living with boyfriends), they should not receive." Another blogger writes, "Holy Communion is available to all sinners who repent, who are baptized, and who are in a state of grace. Bank robbers who openly continue to rob banks are not repentant also cannot receive Holy Communion." ${ }^{117}$

Other churches, such as the United Methodist Church, also have official policies. "The United Methodist Church acknowledges that all persons are of sacred worth. All persons without regard to race, color, national origin, status, or economic condition, shall be eligible to attend its worship services, participate in its programs, receive the sacraments, upon baptism be admitted as baptized members, and upon taking vows declaring the Christian faith, become professing members in any local church in the connection." But later they clarify that they on the one hand "shall be responsible for ensuring that no board, agency, committee, commission, or council shall give United Methodist funds to any gay caucus or group, or otherwise use such funds to promote the acceptance of homosexuality" but on the other they are not to "violate the expressed commitment of The United Methodist Church 'not to reject or condemn lesbian and gay members and friends." 118 While these statements may seem

\footnotetext{
117 blogger 2011, "Should Gay Men Take Communion?", Catholic Answers, 5/2011, http://forums.catholic.com/showthread.php?t=564664 (accessed February 9, 2013).
} 
contradictory or vague, it may very well be done to maintain courtesy in their bigoted views. An article written by a UMC pastor and published on the denomination's website calls for a more disciplined body of pastors so that there will no longer be church leadership "breaking covenant" in striving to pass samesex marriage in the church. This is not the only article, the only church, or the only denomination that passes discriminatory policies that gloss over their exclusionary practices. ${ }^{119}$ Thus, in the Roman Catholic tradition, and in the exclusionary Protestant churches,${ }^{120}$ queer people are rejected and condemned each time they are turned away from participating in receiving the elements of bread and wine. ${ }^{121}$

The next chapter will explore the various types and degrees of violence experienced by queers in their condemnation and exclusion from the communion table.

${ }^{118}$ The United Methodist Church 2008 Policy Manual 161.F http://archives.umc.org/interior.asp?mid=1324 (accessed January 23, 2012).

119 McKracken, Sky. Some hard truths about the UMC, including that homosexuality isn't to blame. 2012.

120 In light of Chart B, even though overall Protestant denominations are split with regards to the inclusion of queer people, those that do not allow queer people have having much larger numbers in terms of membership, and thus make up the majority of Protestants in the U.S.

${ }^{121}$ The argument that opposes trans ${ }^{*}$ people from participating in the Eucharist is largely based on the same clobber passages. Deuteronomy 32:5 is also used to condemn gender nonconforming people as well as to reinforce gender roles, and more specifically gender expression and presentation through gendered clothing prescribed for male and female. However, there is absolutely no direct Biblical prohibition against trans* identities, or intersex individuals. Any support is under the presupposition that trans* people are simply homosexuals, and the same clobber passages, are used to exclude them along with queer people. This demonstrates a complete lack of understanding in regards to the differences between sexuality and gender identity. Sexuality refers to bodies that engage sexually with other bodies. Gender identity is how someone may understand their own identity in respect to the socialized gender structure of the day. 


\section{SPIRITUAL VIOLENCE}

Spiritual violence can take on many forms for people of all faiths. Looking at mainstream U.S. Christian liturgy, referring to both Roman Catholic and Protestant denominations, this type of violence refers to the intangible, or spiritual, harm done to people by religious institutions or leaders. Spiritual violence is done to people of faith through various avenues. Religious abuse is defined as the promotion of messages that contain abusive language by religious communities or threatening acts directed toward the queer person. ${ }^{122}$ The spiritual violence that is studied in the present thesis is the harm done to queer people under the assumption that scripture supports the marginalization of queer people. Spiritual violence carries out and perpetuates the view that Christian identity and queer identity are mutually exclusive, that queer identity is incompatible with Christian teaching.

Rembert Truluck, an author on spiritual violence, looks to Matthew 23 where "Jesus spelled out in detail the destructive power of abusive sick religion in obscuring the truth about God and God's will for all people."123 Truluck understands that excluding queer people from church life is a sign of "sick and abusive religion." Spiritual violence causes harm to the spirit and spirituality of the individual resulting in psychological and emotional harm, as well as cruelly severing people from their faith. Ritualized spiritual violence is when harm to the

\footnotetext{
${ }^{122}$ Super, John T.; Jacobson, Lamerial "Religious Abuse: Implications for Counseling Lesbian, Gay, Bisexual, and Transgender Individuals", Journal of LGBT Issues in Counseling, 5, 180-196.

${ }^{123}$ Rembert Truluck, Spiritual Violence, Whosoever.org 2001 http://www.whosoever.org/v5i6/violence.html (accessed November 12, 2012).
} 
spirit is embedded in ritual. In other words, spiritual violence inflicted during the sacrament of Eucharist or Holy Communion offered by mainline denominations is a prime example of ritualized spiritual violence. Building on Truluck's framework of spiritual violence, ritualized spiritual violence will be explored within the sacrament of Communion, or Eucharist. More specifically I examine violence done to queer people through denial or exclusion from these rituals. Truluck mentions, among others, some ways this form of violence is executed are by shunning, humiliation, the inculcation of self-hate, the "polluting of spiritual resources." ${ }^{124}$ For exclusionary churches, the sacrament of Communion, or Eucharist, incorporates all five of these elements of spiritual violence towards queers.

Spiritual violence is incorporated into the liturgy and then repeated monthly or weekly, becoming synonymous with worship, community, salvation, and grace. The present thesis shows how violence is experienced by queer people as well as taking note of some of the violence produced through homophobic discourse that inevitably becomes embedded within the system of exclusion through the participation in Communion. Ritualized spiritual violence occurs in a cyclical pattern that reinforces its exclusive message within a Christian ritual that is specifically designed for inclusion. The ritual, and the silent understanding that not all are worthy to receive the body and blood of Christ, reinforce the indoctrinated segregation creating a self-propagating cycle of spiritual violence. It can be argued that violence violates the sanctity of the

${ }^{124}$ Truluck, http://www.whosoever.org/v5i6/violence.html. 
sacrament itself; however, the concern of my thesis is how marginalizing queer people is doing violence to queer people, but also to non-queer Christians who may perceive the exclusion of queer people during liturgical worship as a validation of their internalized homophobia.

\section{Humiliation}

In a recent news article, newly appointed Archbishop Salvatore Cordileone of the San Francisco diocese was quoted as likening legalizing same-sex marriage to "legalizing male breastfeeding." ${ }^{125}$ Cordileone stated that marriage is not discovered through theology, but argues that "marriage is in nature" and theology simply builds on that. The direct connection made is that, just as males do not produce milk, so homosexual couples do not produce children. While the Catholic Church does not have an official stance on transgender or transitioning people, their statement is simply ignorant of individuals that identify as men and still have the full capacity to breastfeed.

The main goal of this statement can only be viewed as hostile messaging resulting in condescension and humiliation. "Male breastfeeding", for the vast majority of people who are ignorant of trans* issues, will likely come off as humorous. The humor rests on a strict sexual dimorphism that implies the humor in the absurdity of a male breast-feeding a baby. The implication that breast-

\footnotetext{
${ }^{125}$ Scott Roberts, "Catholic Archbishop of San Francisco: Allowing gays to marry 'is like legalising male breastfeeding'”, Pink News, 01/29/2013, http://www.pinknews.co.uk/2013/01/29/catholicarchbishop-of-san-francisco-allowing-gays-to-marry-is-like-legalising-male-breastfeeding/ ( accessed February 13, 2012).
} 
feeding is comical no doubt will offend some women. Ignorant and humiliating statements infuriate the queer community as well as aggravate relations between queer and non-queer people. Queer people have been compared to pedophiles, zoophiles, and made the target of a slew of jokes. Cordileone's statement dismisses queer unions with a remark, whose only function is to humiliate.

Humiliation is a tactic used by many churches to pressure queer people into ex-gay therapy or celibacy. Humiliation can impact employment, family relations, social status, and can be a great motivator for people to continue to bully, embarrass, or harass queer people. When leaders in the Church are free to make public statements that humiliate and serve to further ostracize queer people it easily becomes a license for others to make similar statements at schools, churches, and public spaces. Churches more frequently express this sort of public humiliation in attempts to safeguard their sacred spaces. The sacraments of marriage, baptism, and communion are spaces quite well guarded. George Weinberg, a psychologist who authored Society and the Healthy Homosexual in 1973 in hopes of challenging homophobia in the field writes, "Ridicule is often the precursor to acts of violence." ${ }^{\text {"126 }}$ Assumption Church, a Catholic congregation in Minnesota, denied an entire family Communion for their support of their son's marriage to another man. ${ }^{127}$ Although the statement made by Cordileone does not physically harm queer people, the

\footnotetext{
${ }^{126}$ George Weinberg, Society and the Healthy Homosexual, Garden City: Anchor Books. 1973, 75.

${ }^{127}$ Andrew Belonsky "MN church denies family communion over son's gay marriage support", Towlroad, 2/15/2012 http://www.towleroad.com/2012/11/mn-church-denies-entire-familycommunion-over-gay-marriage-support.html (accessed January 13, 2013).
} 
motive here is to create contempt, so that there is a deepening of disregard and repugnance for queer people. Reminding congregants that they are 'not worthy' by public rejection cannot be the intention Jesus had in mind when he said, "do this.... In remembrance of me."

\section{Shunning}

Many queer people come to truly believe that even though they have tried to change they are not worthy of God's love. Too many queer people, after "failing" in their efforts to grow into a (hetero)sexual and/or express themselves in heteronormative ways, turn to suicide. They are repeatedly told that either way, whether they continue to live as they genuinely are or they kill themselves, they will burn in Hell. This judgment from God is not enough; churches that have practice excluding queer people also routinely cast this community aside and push them out of baptism, communion, marriage, and other liturgies or community spaces, such as ordination or even sometimes membership. Sadly, even more people who identify as queer turn away from Christianity, not from lack of faith in God, but from the internalized conviction that "homosexuality [or expressing their gender in non-heteronormative ways] is incompatible with Christian teachings." ${ }^{128}$ Shunning is the main component of the spiritual violence that occurs when queer people are excluded from the sacrament of Communion, but it is in the aftermath of the exclusion that much of the damage done to them can be observed.

\footnotetext{
${ }^{128}$ United Methodist Church, www.umc.org. Accessed February 12, 2013.
} 


\section{Self-Hate}

Self-hate is the internalization of negative messages about one's own identity, body, behavior, and/or thoughts. Exposure to hate speech leads to poor self-esteem, guilt, shame, self-destructive behavior, self-deprecating thoughts, and a myriad of intersecting negative emotions. In God Hates Fags, Michael Cobb analyzes the rhetoric of religious violence by groups such as Focus on the Family and the Christian Coalition; he also analyzes some of the hate rhetoric of their infamous leaders, such as Fred Phelps, who coined the phrase that titles the book "God hates fags". ${ }^{129}$ Cobb states that "religious language has always been a part of the strongest, united descriptions of American communities, with roots that are puritanical, constitutional, and persist today...the expression of the religious intolerance of queers is a kind of hate speech that serves an important role in the rhetoric of American society," adding "this hatred is mainstream." 130

The messages promoting self-hate can be found everywhere in society, more so for the millions of families who maintain close ties with their religious communities and liturgical practices. The aim of Cobb's book is to illustrate how queer people transform hatred and religious hate speech into "conventional structures of national belonging,,"131 a queering of hate, so to speak, to be used as a stepping stool away from guilt and shame. By comparing religious hatespeech toward queer people and hate speech used in the past toward other

\footnotetext{
${ }^{129}$ Michael Cobb, God Hates Fags: The Rhetorics of Religious Violence, 2006, NY: University Press, 3-7.

130 Ibid., 3.

${ }^{131}$ Ibid., 11.
} 
previously disenfranchised groups, queer people may find empowerment and hope. The United States has a history of social justice movements, and so this legacy of religious oppression may be seen optimistically, as one step closer to religious acceptance.

Self-hate has also been described as "guilt with its companions shame and low self-esteem". ${ }^{132}$ Cobb's observations are positive as much as they are useful in powerful ways, but, what happens to queer people between the time they hear their first anti-gay sermon directed with contempt and hatred until the time they reject hateful messages and move forward, unabashedly queer? The journey for many queer people of faith, before self-acceptance (if achieved), often includes participation in ex-gay organizations. Exodus International, for example, is a worldwide organization whose priority is to help "homosexuals grow into heterosexuality through Christ." There are various organizations with similar goals to that of Exodus International, and many other political groups working to sway legislation against what the religious right terms as "special rights" for queer people. Most of these groups in the U.S. identify as Christian. ${ }^{133}$ To be like Christ then is synonymous with being heterosexual. ${ }^{134}$ Anti-gay Christian groups have used both religious and mental health rhetoric to describe the "homosexual sin/illness." In Ex-Gays, a book partially funded by Exodus

\footnotetext{
132 John McNeil, Taking a Chance on God, MA: Beacon Press, 1996, 54.

${ }^{133}$ Christian here includes Catholic, Protestant, and other Christian movements including Pentecosta and Mormons, who both affirm exclusionary practices.

${ }^{134}$ Ibid, 11.
} 
International, a group of psychologists attempted to do serious and unbiased research to come to some conclusion whether Exodus International, and other groups that claim that homosexuals can change or become heterosexual, were correct. The book concludes by stating that there were no conclusive results. While some (homo)sexuals did indeed move on to (hetero)sexual relationships, these numbers did not make up a significant population. ${ }^{135}$ While the view that sexuality is fluid and also that (homo)sexuality is not fixed is promoted by queer theory and celebrated by the queer community, there is still a long way to go for many people. For these studies to be of any scientific value it would be interesting to see these same studies performed in the (hetero)sexual community. Can (hetero)sexuals be changed or become (homo)sexual? These studies conclude that sexuality is a part of the make up of people; however, they are also deeply discriminatory, hurtful, and abusive. While there are people that truly believe they do not want to live a "gay lifestyle" and some believe there should be help offered to help un-gay them, this sort of assistance would never be celebrated for heterosexual people that would like to un-straight themselves. It would make more sense to treat people to love their bodies and their sexuality as heterosexuals. The same assistance, to love their bodies and their sexuality, must be offered to queer people who have internalized self-hate, instead of assist them in going against the grain of their desires.

\footnotetext{
135 Jones, Stanton L.; Yarhouse, Mark A., Ex-Gays? A Longitudinal Study of Religiously Mediated Change in Sexual Orientation, Downers Grove: InterVarsity Press, 2007.
} 
In Matthew 9:10-3 it states that: "And as he sat at the table in the house, behold many tax collectors and sinners came and sat down with Jesus and his disciples. And when the Pharisees saw this, they said to his disciples, 'Why does your teacher eat with tax collectors and sinners?' But when Jesus hear it, he said, 'Those who are well have no need of a physician, but those who are sick. Go and learn what this means, I desire mercy, and not sacrifice. For I care not to call the righteous, but sinners."' In the U.S., even the most zealous of religious organizations are beginning to admit that there is no "cure" to homosexuality, stating that some can "change" while concluding those that cannot should stay celibate. ${ }^{136}$ The justification accounts for the large amount of numbers of gays in the U.S. who believe Christ can change their behavior, through a life of celibacy. ${ }^{137}$ In anti-gay discourse homoerotic behavior or attraction transforms the individual's thoughts into a labeled identity, the "homosexual." The individual then can only be a member of the church if they maintain a celibate life, rejecting their sexuality and abandoning sexual intimacy. Anti-gay denominations maintain that celibacy (avoidance of sexual intimacy with same sex/gender individuals) and total rejection of sinful and deviant behavior is the only path to a Christian life for queer people. The discriminatory stance is wholly backed with religious appeals to the clobber passages. However, in the passage from Matthew above, Jesus clearly states that he does not need sacrifice. Celibacy is

\footnotetext{
${ }^{136}$ Ibid., conclusion.;Also found on Exodus website, http://exodusinternational.org/?s=celibacy.

${ }^{137}$ Exodus International, "Big Foot, Nessie, and Exodus International", Exodus Q\&A, 10/09/2009 http://exodusinternational.org/2009/10/big-foot-nessie-exodus-international-2/ (accessed January 7, 2013).
} 
a great sacrifice asked of (homo)sexuals, especially when the scholarship pointing to same-gender relationships as sinful or against God is steeped in biased scholarship.

\section{Polluting of Spiritual Resources}

The Bible speaks about defilement and warns against it, describing instances of physical defilement, the defilement of the land, and defiling morals. ${ }^{138}$ An example of this is Christianity's focus on sexual relations and emphasis on celibacy: pre-marital, in priesthood, and most recently, as prescribed for (homo)sexuals. Defilement, or pollution of resources, can then not only lead to the pollution of the body, or to pollution of land and food, but can also lead to pollution of ideals of behavior, and can also be seen as pollution of the "rules" for behavior. There has been a recent call for celibacy for (homo)sexuals in the church, but is the church polluting the morals or are queer people polluting morals by expecting a life of equal sexual fulfillment as (hetero)sexuals?

The Roman Catholic Church, Methodists, and American Baptists expect a life of celibacy for people that are attracted to the same sex. ${ }^{139}$ Their stance on homoerotic behavior or a (homo)sexual "lifestyle" stems from their particular understanding of the nine Scripture passages treated above. The "polluting of spiritual resources" leads to spiritual violence done to all people. The scripture

\footnotetext{
${ }^{138}$ Phillip Wendell Crannell Bible Encyclopedia, "defile", http://bibleencyclopedia.com/defile.htm.(accessed January 23, 2013).

139 "Same-sex" is used here instead of same-gender to parallel the language used by exclusionary churches.
} 
has been read and understood through a particular filter that ultimately works to separate queer people from religious figures and church communities. These religious figures, church communities and scripture itself are all resources that all people will need and seek, especially for queer people during their journey "out of the closet" or back into a life of faith. Mainstream Christian spiritual resources such as, the Bible, commentaries, articles, books, religious leaders, and communities are all denied to queer people. In most cases, the spiritual means for daily living not only make no mention or reference to queer people and in many cases, frame homosexuality as a sin. Until recently, theological discourse was exclusively produced by the voices and out of the experiences of the dominant religious class, (hetero)sexual men, whose ideals aligned with the traditions of other (hetero)sexual men. God warns against defiling the land by planting mixed seeds and polluting not only the land but also the fruits of the land. ${ }^{140}$ For many queer people, the misuse of the Bible represents the defilement, or pollution, of spiritual resources. As can be seen, the Bible is a foundational resource is the Bible, and when it is polluted through misinterpretation, its fruits will also be polluted. ${ }^{141}$

In an article published by Catholic News Service titled "Vatican says 'sexchange' operation does not change person's gender" that exploded on the web,

${ }^{140}$ Deuteronomy 22:9.

${ }^{141}$ Deuteronomy 22:9. 
the Catholic Church, in response to transsexual or surgically transitioning people, declared: ${ }^{142}$

- An analysis of the moral licitness of "sex-change" operations. It concludes that the procedure could be morally acceptable in certain extreme cases if a medical probability exists that it will "cure" the patient's internal turmoil.

- A provision giving religious superiors administrative authority to expel a member of the community who has undergone the procedure. In most cases of expulsion from religious life, the superior must conduct a trial.

- A recommendation of psychiatric treatment and spiritual counseling for transsexual priests. It suggests they can continue to exercise their ministry privately if it does not cause scandal.

- A conclusion that those who undergo sex-change operations are unsuitable candidates for priesthood and religious life.

- Repeat of the first-- A conclusion that people who have undergone a sexchange operation cannot enter into a valid marriage, either because they would be marrying someone of the same sex in the eyes of the church or because their mental state casts doubt on their ability to make and uphold their marriage vows.

- An affirmation of the validity of marriages in which one partner later undergoes the procedure, unless a church tribunal determines that a transsexual disposition predated the wedding ceremony.

The argument is laid out in such a way that it justifies the exclusion of queer people by the church. People who engage in same-gender sexual relationships are exempt from communion because they do not repent, and thus, are not in a state of grace and may not partake of communion. Queer people

\footnotetext{
142 John Norton9/19/2011, "Vatican says 'sex-change' operation does not change person's gender", Catholic News Service http://ncronline.org/news/vatican-says-sex-change-operationdoes-not-change-persons-gender (accessed January 23, 2013).
} 
(including trans* people who identify as hetero-sexual) must take the blame and responsibility upon themselves to "change" and live a celibate life. In the case of trans* people who are transitioning or identify as something other than what is assigned on their original birth certificate, they must live a life that is framed and governed by the assignment of "male" or "female" that was given to them at birth, a decision which is based solely on external genitalia. One of the most shocking declarations is the expulsion, wholly and completely, from religious life after a "sex-change" operation (see second bullet above). This implies that opportunities to repent, therefore, are denied to transitioning people. The reason given for the expulsion above is even more horrific; "because of mental instability." ${ }^{143}$ The pollution, in this case cis-heterosexist exegeses, clouds the meanings and intentions in the narratives of the original Bible passages. In the example of religious oppression and violence from the Vatican stance on "sexchange" operations, the clobber passages are no longer distinguishable from the intricate oppressions the traditional interpretations or mis-representations produced. Doctrine and dogma have the authority over sexuality and over the punishments for transgressing people. The privileged position of priests and ecclesial authority is exclusively embodied in cis-hetero-male bodies.

Protestantism does not lag behind in similar oppressive structures; they too promote hate-speech and disperse it via preachers, teachers, friends, and

\footnotetext{
${ }^{143}$ Ibid., accessed January 23, 2013. The usage of "religious life" is ambiguous. It was previously used in the second bullet to refer to members as well as priests, , so this section makes the assumption that "religious life" in the fourth bullet means for priests as well as for members.
} 
family members who relay these continuously evolving homophobic messages, also polluting the Word of God. ${ }^{144}$

${ }^{144}$ Nancy Wilson, Our Tribe; full cite. 


\section{Responses to Spiritual Violence}

Despite what has been done to obscure the fact, there is much more biblical support for queer people to feel affirmed in church life, than to feel rejected by it. In a letter to the Galatians Paul writes, "There is no longer Jew or Greek, there is no longer slave or free, there is no longer male and female; for all of you are one in Christ Jesus." (3:28) The passage in Galatians was also quoted during other social movements, by feminist and other reformers. In Galatians marginalized queer people can feel renewed in hope and faith. Paul may not have understood exactly how it would affirm people today, but the message from God that all people are welcome at God's table, is widely understood.

The Greatest Commandment, to love God with all of yourself and to love thy neighbor as you love yourself, affirms the love of God, people, and Self. ${ }^{145}$ Shunning, humiliation, and the promotion of self-hate are not condoned anywhere in the Bible. In Corinthians, Paul's vice list includes behavior which was not acceptable, however, he ends the letter admonishing against judging others. ${ }^{146}$ John $3: 16^{147}$ is often quoted by queer people with an emphasis on "whosoever", joining the legacy of others that have leaned on this passage for support. Everyone is welcome.

\footnotetext{
${ }^{145}$ Matthew 22:36-40

1461 Corinthians 5:9-11

${ }^{147}$ (NRSV)“For God so loved the world that he gave his only Son, so that everyone who believes in him may not perish but may have eternal life."
} 
Queer theology has also opened up space for radical and different rituals to manifest, which are seen as actions to move towards transformation and spiritual growth. Some of new rituals are responses to existing oppressions, such as the sacrament of "coming out." Queer people's varied experiences in the sacrament of Communion have also expanded categories of gender and sexuality traditionally found in these spaces.

\section{"Coming Out" As Sacrament}

Religious abuse may cause individuals to internalize hatred of self, feel humiliated and shunned by the community. The results are disastrous. Statistics maintain that queer youth are three times more likely to attempt suicide than their (hetero)sexual counterparts. ${ }^{148}$ What "coming out" really means is that individuals have come to affirm their non-normative sexual attractions or non-normative gender identities and want to share this delicate information with people who are important to them, such as family, spiritual leaders, friends, and teachers. The information of someone's sexual orientation or gender identity in the wrong hands could easily, and often does, escalate into the systematic marginalization of the person.

The three institutions that youth or adults can turn to as resources for personal and spiritual growth are the family, church, and school, all of which can be hostile to queer and questioning youth and can result in the systematic

\footnotetext{
${ }^{148}$ American Association of Suicidology Suicidal Behavior Among Lesbian, Gay, Bisexual, and Transgender Youth act Sheet, 2008, http://www.suicidology.org/c/document library/get file?folderld=232\&name=DLFE-334.pdf (accessed October 10, 2012).
} 
marginalization of queer people, with each institution closing their doors. The systematic marginalization means that each institution shuns the person, humiliates them, and does not allow them to benefit from guidance, nourishment, or support.

Coming out is not a fixed moment in time. Coming out is a process. "Coming out" for a queer person of faith involves making the connection between the physical and spiritual in their discernment process. It also involves some form of reconciliation with Scripture and with religious oppression.

For queer people of faith, "coming out" involves coming out as lesbian, bisexual, trans, gay, or queer to faith communities. It also involves coming out as Christian to queer communities. Queer people have felt such violence and hostility, most of which has been religious-justified, that Christianity has lost popularity as an inclusive faith. Many times for a queer person of faith it is just as difficult to affirm their faith in queer spaces hostile to Christians as it is to affirm their sexuality in Christian spaces hostile to queer people.

At every turn queers hear the clobber passages repeated back to them, and despite their faith, and even when they lack all sexual experience (many queer people come to understand their attraction as (homo)sexual but have not actively engaged in sexual activity), they hear that they are an "abomination" and are ostracized due to their queerness from church life and liturgy. Youth experience compulsive homophobic spaces from pre-school to adulthood, resulting in their isolation, depression, and severe alienation. In many cases, youth from fundamentalist families experience this homophobia in deeply 
damaging ways, as when the religious right engages in discourse that equates queer people with the Devil. ${ }^{149}$ There are still thousands of schools in the United States that openly discriminate against queer students. ${ }^{150}$ Confronted with a queer student, the school then turns to the family, the child's legal guardian and defender of the child's soul. The family, if they are not "affirming," which is often the case, then turns to the church. Any resource or hope for affirmation is to leave the faith. Insurrection is corrected by medieval-like punishments: labeled mentally ill (incarceration), forced/coerced into ex-gay therapy (exorcism), equated to the worst sin imaginable (burned at the stake), or disowned (excommunicated/exiled). In other words, similar cleansing tactics applied during the Crusades are being used against queer youth in the U.S. today.

The Metropolitan Community Church, an open and affirming church organized and led by queer people, respects the "coming out" process as a sacrament without the need for further liturgical practices. ${ }^{151}$ John J. McNeil describes this process as involving "mourning" the need to "die in one's old identity" and the letting "go of the hope of belonging to and being accepted by the straight world", each step in this mourning process allowing possibilities of

\footnotetext{
149 Ibid., 15.
}

\footnotetext{
${ }^{150}$ At the time of writing this paper there is controversy in Georgia where over 100 faith-based schools, benefitting from a tax break that converts state money into private scholarships, are using those funds while simultaneously openly expelling students who identify as LGBTQ. Backed by State Money, Georgia Scholarships Go to Schools Barring Gays, Kim Severson, 2013.

${ }^{151}$ Mona West, Coming out as Sacrament, MCC Church, http://mccchurch.org/download/theology/sexandspirit/ComingOutSacrament.pdf (accessed November 16, 2012).
} 
spiritual growth. ${ }^{152}$ There is an extra element in the sacrament of "coming out" in that it is not only a personal connection with God, but also a personal connection with others. To "come out" inherently means to share the knowledge of who one is with others. The act symbolizes both the intensely personal vulnerability of one's Self and a respect for the Other through authentic revelation. The sacrament of the Eucharist also involves a myriad of self-reflections and personal experiences as well as authentic communication with others. For some, such as Robert Goss, "the act of coming out is most like the sacrament of Eucharist because both involve a sacrifice and an offering that creates ...communion with God and with others." ${ }^{\prime 153}$

\section{Queer Identity in Eucharist}

What follows are two case studies to demonstrate how queer people "queer" Eucharist by their presence. Following the understanding that embodiment of queer identity in the next few cases means to understand that the marginalized, oppressed, and discriminated sexual identity or gender identity is personified, represented, or given form in the body of a person. The next two cases involve embodying the queer, and how this is reconciled during the Eucharist, when Jesus is embodied in the elements.

\footnotetext{
152 McNeil, Taking a Chance on God, 72.

${ }^{153}$ Robert E. Goss, Jesus Acted Up: A gay and lesbian manifesto San Francisco: Harper, 2003, 35.
} 


\section{Case Study \#1:}

Winnie S. Varghese is an Episcopalian priest and believes that people have been mis-instructed to believe the "heretical norm" that they are not worthy of sharing at the table of the Bread of Life. Her theology is rooted in both traditional understanding of Scripture as well as contemporary understandings of Democratic justice. She attributes the Episcopalians' open practice of the Eucharist to their deep commitment to the equal worth of all people. ${ }^{154}$

Episcopalian acceptance of queer participation in the sacrament is defiant of mainstream liturgical norms. Episcopalians, as the "Protestant, yet Catholic" denomination have defied the binary that had been created with the birth of Protestantism. They transgress the boundaries, or violate the lines, between Catholics and Protestants. They transgress the boundaries between Catholics and Protestants, and within Eucharist, the boundaries that demarcate worth are expunged so that all people are welcome at the Lord's table. Both Protestants and Catholics are provoked by Episcopalian Eucharistic practice. The provocation forces churches to look at their own prohibitions for participation and to reflect on their exclusionary traditions. Both media attention and word of mouth

\footnotetext{
${ }^{154}$ Hinze, Christine Firer, and J. Patrick Hornbeck II, . "More Than a Monologue: Sexual diversity and the Catholic Church." More Than a Monologue. Bronx: Fordham University Press, . 1-122.; both are shortened biographies of longer auto-biographies found in the same manuscript (forthcoming). (Winnie S. Varghese, "Lord, I Am (Not) Worthy to Receive You". In Christine F. Hinze and J. Patrick Hornbeck II, More Than a Monologue: Sexual Diversity and the Catholic Church (Bronx, NY: Fordham University Press, forthcoming) 123-134 (.Eve Tushnet, "O Tell Me the Truth about Love", 2013 (forthcoming) 40-46.
} 
information are subversive, producing discursive practices that carry the defiance into wider society.

As a female priest, Winnie herself also embodies defiance for the impositions of sex and status constructions engendered by the Roman Catholic priesthood. She defies the traditional ordinance of males-only for priesthood and as queer, she blurs the gender roles that are traditionally assigned to Christian women. As a woman of status and ecclesial authority she queers hierarchal gender roles that persistently prescribe women to be compliant and subordinate. Within Eucharist, Winnie expunges all the boundaries that have been drawn against queer people, subverting the authority over what demarcates sufficient individual worth to warrant participation. For Episcopalians, the receiving of the elements is a form of fellowship with other Christians, the only prerequisite being that of baptism. ${ }^{155}$ In this case, the open and affirming meal confronts the stigma and the dominant dogma that deny queer people. Instead, Winnie rejects traditional authority, and welcomes everyone to share in community, fulfilling the purpose "to be in communion with God and each other". 156

\section{Case Study \#2:}

Eve Tushnet came out when she was thirteen and lived free of guilt from her non-normative sexual identity. At the age of twenty she converted to Catholicism and attributes her easy conversion to the lack of baggage from

\footnotetext{
155 The Domestic and Foreign Missionary Society 2012, Holy Communion, Episcopal Church, http://www.episcopalchurch.org/page/holy-communion (accessed January 23, 2013).

156 Ibid. http://www.episcopalchurch.org/page/holy-communion (accessed January 23, 2013).
} 
childhood. Her certainty that the Church understood more about sexuality overruled her certainty that her (homo)sexuality was morally neutral. She strives and admittedly struggles with celibacy as the Church teaches, and concedes that what matters most to her is to be able to receive the Eucharist.

Within the transgressive use of the word "queer," to queer the Eucharist then means to challenge, question, provoke, or confront the norms found in the sacrament. The norms in the sacrament of Communion would be exclusionary practices and social justice concerns. Eve's story demonstrates her complacent acceptance of the rules imposed on her by the Roman Catholic Church. Before her conversion she did not carry any guilt or shame over her relationships with other women; in fact she was convinced it was morally neutral. However, after her conversion to Catholicism, Eve can then be seen to conform to discriminatory Catholic precepts on (homo)sexuality and celibacy.

Despite her conformity to Catholic celibacy rules she can also be seen as a radical within her faith community. As an "out" celibate lesbian, Eve confronts the norms of (hetero)sexuality within the ritual. As a celibate Catholic in church life she symbolizes the Other that the rules themselves have positioned as opposition. Eve's presence forces her peers to acknowledge a queer person's varied experiences. In this way Eve commands the limits of the sacrament to widen and affirm her existence. It is transgressive for a faith that is deeply traditional, and steeped in strict customs, to make space for her in fellowship as an "out" celibate Catholic. Her presence in Eucharist puts her, and her non- 
normative identity, in direct relation with others during fellowship, which serves to reintegrate queer people into church life and allow queer experiences visibility. ${ }^{157}$

\section{Queering the Eucharist}

For most people the ritual reaches its pinnacle when the wafer and wine unite the receiver with Jesus as God, community in fellowship, and miracle in sustenance. The ritual is fundamental to all Christians because of the very qualities of renewal, hope, and transformation it possesses. These qualities are especially understood and respected by people who feel they have embodied this journey; in fact, in queer culture, religious as well as secular spaces have assimilated the values of renewal, hope and transformation because of the history of oppression, the process of 'coming out', and the multiple conversions in identity during a queer person's journey. Therefore, when queer identity meets Eucharist, there is a powerful instinct that reconciles sexuality and spirituality. Identity is not compartmentalized, categorized, or segregated. The full Self is there, whether as Catholic in a state of grace accepting the actual body and blood of Christ, or as with Baptists, in fellowship and remembrance. The queer person no longer feels "unworthy" because while every tradition believes something different happens during Communion, or Eucharist, what actually

\footnotetext{
${ }^{157}$ In a 2005 news article, The New York Times reported a possible new policy from the Vatican, to no longer ordain gay or bisexual celibate priests. This would be a policy change within Catholicism, and it raised eyebrows as to how, exactly, this new policy would be enforced. Laurie Goodstein 09/15/2005, "Vatican to Check U.S. Seminaries on Gay Presence", The New York Times. This policy has implications for all celibate and 'out' queer people, marking their acceptance into the sacrament preliminary and precarious, but also controversial, transgressive, and radically queer.
} 
occurs during the ritual is subjective and personal. It is between God and the participant. When both a stigmatized sexuality or gender identity and deep faith are reconciled, the transformation that occurs during this ritual can be described as love, self-acceptance, and confirmation of faith, grace or justice.

When queer people are included in Eucharist, what this also symbolizes is that the entire church community is in agreement to discard traditional homophobia and transphobia. There are other voices and experiences and stories in the ritual of the sacrament that feel excluded or have felt excluded, and these experiences too are accepted when queer people are affirmed because queer people reflect every faith, tradition and religion. They experience every age, every economic sector; they come from every culture, and of course, every sexuality and gender. The space that queer people represent is a space of multiple truths. Those truths, those stories, are all accepted and affirmed in God during the sacrament. The ritual comes to symbolize God's radical inclusion of all people at God's table, erasing the markers that deem people "unworthy". This "re-claiming" of sacred space for all people of faith is what early Christianity, and indeed, Jesus himself, preached.

As explained earlier, God's mercy and grace are embodied in the human form. The spirit/body dualism has led to the negation of bodily senses in the past in the forms of asceticism and monasticism, as well as the denial of sexuality. However, embodiment can be another word for incarnation, and just as the 
"Word was made flesh..."158, human and divine made into One, so should the body of Christianity be understood as a whole. In this case, sexuality as it is now reduced to genitalia, does not embody the gifts of the Incarnation or the Eucharist. A whole body yearning to touch, to love, to be one with God comes to the table to take the elements and to receive God, Jesus, and the Holy Spirit. The receiver takes the elements in what is a celebration of both death as well as life. This is a powerful parallel to the teachings of Jesus who brought people from the outskirts of social life into his sacred inner circle. To "queer" the sacrament, therefore, means a return to the inclusive radical Christianity Jesus intended.

158 John 1:14 


\section{CONCLUSION}

Queer theology challenges the categories of sex and gender, and brings to light interpretations that work outside of the normative frameworks to produce queer exegeses of the clobber passages. John Boswell and Bernadette Brooten's historical approaches answer different questions than have been asked in the past. Deeper understandings of ancient cultures and languages, with specific inquiries with respect to sex, gender, and modern understandings of patriarchy and sexism, have then fueled the work of theologians, such as Robert Goss and Mark D. Jordan. Specifically looking at Bible passages that have been used to support heterosexism and homophobia, ecclesial authorities often cite the so-called "clobber passages" to validate claims that "homosexuality is incompatible with Christian teaching". The clobber passages, the passages that are believed to specifically condemn same-gender relationships, have been interpreted, and sometimes selected, within a cis-hetero-patriarchal framework of gender. Many churches believe that one must be baptized, or like the Roman Catholic Church, believe there is a discernment and purification process before Eucharist, with additional exclusions for "mortal sins." United Methodists, American Baptists, and Fundamentalist churches agree that homosexuals should not join in Communion, and even when it is simply understood as fellowship with God and others, they are not allowed in. These churches agree that homosexuals should not join in the sacrament, cannot commune with God in a faithful way, and are not worthy of receiving the body and blood of Jesus Christ. Mistranslations and misunderstandings in the Bible continue to be used to self- 
righteously and publicly sever queer people from church and church ceremonies, creating another unnecessary division between queer people and people who are termed as "not-queer." One of the results is the demonization and marginalization of non-normative identities from sacred religious rituals. As things are, new liturgies are being birthed as a result from the exclusion from traditional rituals, and these have become necessary in the lives of queer people of faith.

Paul is quoted in 1 Corinthians 11:30-32 as writing, "For this reason many of you are weak and ill, and some have died.31 But if we judged ourselves, we would not be judged.32 But when we are judged by the Lord, we are disciplined so that we may not be condemned along with the world." The Eucharist meal is offered to everyone (1 Corinthians 11:23-26). In 1 Corinthians 11:27-29 Paul admonishes partaking in the Eucharist in an unworthy manner. However, even without the benefits of modern scholarship we can see that Paul in,1 Corinthians 11:30-32, condemns those who judge others to judgment directly from God. Although parts of Paul's epistles are territories of debate and contention, his final word is directed to those that judge others. ${ }^{159}$ "Every Christian should live by certain spiritual disciplines, chief among them being the discipline of examining and criticizing ourselves more harshly than we do others." 160

Catholicism, view same-sex activities as one of the mortal sins that exclude one from the Eucharist. The Catholic message is hostile and results in disconnecting queer people from religious resources and spiritual nourishment.

\footnotetext{
${ }^{159}$ Also found in Romans 3:23.

${ }^{160}$ Ellen F. Davis, "Reasoning with Scripture”, Anglican Theological Review, 90(3) 2008, 26.
} 
The beloved sacrament of communion, which symbolizes and concretizes the union with God and neighbor, is represented and governed by the church, and the churches have separately convened and decided who is worthy or not. Many churches believe that one must be baptized, or like the Roman Catholic Church, believe there is a discernment and purification process before Eucharist, with additional exclusions for "mortal sins." The majority of Protestant churches agree that homosexuals should not participate in the practice. Ritualized spiritual violence has devastating effects on all Christians.

The harm caused by religious abuse is here determined to be spiritual violence because it directly affects the individual's relationship with their higher power and spiritual community. Lamerial Jacobson and John T. Super have written specifically on religious abuse and state, "The perception of a religious leader is often nurturing and for most, it can be difficult to imagine that person intentionally or unintentionally abusing a churchgoer; regardless, the abuse does occur." ${ }^{161}$ In response to the various ways that homophobic discourse has led to violence done to queer people by the church, historians, authors, theologians, and scholars in the late $20^{\text {th }}$ century began questioning the authority of the violence. Their work has, in turn, become the foundation for political and social justice work and, especially, for the empowerment of queer people of faith.

It is important to continue looking at how the Bible has been traditionally interpreted, understanding that there is a rich and yet sordid history, and keeping

\footnotetext{
${ }^{161}$ Lamerial Jacobson and John T. Super, "Religious Abuse: Implications for Counseling Lesbian, Gay, Bisexual, and Transgender Individuals", Journal of LGBT Issues in Counseling, 5(3-4),2011, 181.
} 
in mind that the discourse has mostly been produced by culture-bound men living comfortably in patriarchal bliss. Today it is understood that patriarchy produces sexism and misogyny and that these have then led to heterosexism and heteronormativity, which have in turn intersected with yet other oppressions. After a long history of suffering under religious oppression and spiritual violence, some queer people are looking to Scripture as a wellspring of resources to renew their hope and faith.

Queer people must continue to join in Christian theological discourse so that their experiences are also reflected in the ongoing history of Christianity, as well as to continually re-establish the radical queer legacy of justice-seeking that Jesus left behind. Embodiment is as radical a notion as incarnation and Eucharist. Embodiment within the elements, and for sexuality, as well as for incarnation in Christianity is a political act that allows the unity of all people in Christ. Jesus erased the boundaries between his communal table and those that politics, culture, and society that drawn. That unity is what drives queer people of faith to erase the boundaries that politics, culture, and society have drawn but that in Jesus and through unity in him through the elements is erasing once again. 


\section{Implications for Further Research}

A comprehensive study of different church practices and liturgies, and their inclusion or marginalization of queer people is strongly suggested in this work. Along with Eucharist other sacraments, such as marriage and baptism, also routinely exclude queer people. Spiritual violence is experienced by queer people outside of the sacraments and in all areas of church life. It is the hope of this paper to shed light on this new topic and open the door for more study and research directed particularly to violent church practices against queer people.

My thesis is built on the belief that sexual dimorphism is socially constructed but more importantly, that Scripture can be seen to agree that the dissolution of the categories of male/female and masculine/feminine is an aim of Christianity. Some of the implications of this paper include the possibility for further discourse on what a radical Christianity would look like if it were not interpreted or applied in ways that dichotomize gender. Does a radical, queer

Christianity have a normative vision? If so, how would a normative Christianity be kept from exerting normalizing forces that would then serve to oppress?

More work in queer Christian scholarship intersecting with queer theory is needed. Jewish studies and queer theory within other branches of religions would also be welcome in the field. Although some would argue that there is plenty of new scholarship, the argument here points to many misunderstandings and mistranslations of sacred texts; this makes clear the need to continue these studies, as well as revisit historical texts and read anew outside of traditional frameworks. Studies of intersectionality of queer experiences in religion, for 
example with respect to race, would benefit the field tremendously. This would take the intersection of queer theory and religion beyond the study of gender and sexuality and into intersections of class, race, and socioeconomic status. As queer theory continues to grow and expand, these will be exciting new directions for enthusiasts to follow. 


\section{REFERENCES:}

American Association of Suicidology. "Suicidal Behavior Among Lesbian, Gay, Bisexual, and Transgender Youth Fact Sheet." Suicidology .

http://www.suicidology.org/c/document library/get file?folderld=232\&na me=DLFE-334.pdf (accessed 12 10, 2012).

American Baptist Church. "ABC USA." Identity Statement. 112005. http://www.abc-usa.org/what_we_believe/identity/identity-statement/ (accessed 11 20, 2012).

American Baptist Churches USA. "AMERICAN BAPTIST CHURCHES USA: RESPONSES/ACTIONS PERTAINING TO HOMOSEXUALITY." Policy Statements and Resolutions. http://www.abc-usa.org/wpcontent/uploads/2012/06/homosexuality.pdf (accessed 11 22, 2012).

American Psychological Association. Answers to your questions about sexual orientation and homosexuality.

http://www.apa.org/topics/sexuality/orientation.aspx?item=8 (accessed 1 $23,2013)$.

Burke, Daniel. Methodists Uphold Policy that Calls Homosexuality 'Incompatible with Christian Teaching'.May 2012.

http://blog.christianitytoday.com/ctliveblog/archives/2012/05/methodists _upho.html (accessed 01 27, 2013).

Butler, Judith. Gender Trouble: Feminism and the Subersion of Identity. New York: Routledge, 1990.

Butler, Judith, Jurgen Habermas, Charles Taylor, and Cornel West. The Power of Religion in the Public Sphere. New York: Columbia University Press, 2011.

Bailey, Derrick Sherwin. Homosexuality and the Western Christian Tradition. London: Longmans, Green and Co., Ltd., 1975.

Beemyn, Brett. "The Silence Is Broken: A History of the First Lesbian, Gay, and Bisexual College Student Groups." Journal of the History of Sexuality 12. 2 (2003): 205.

Belonsky, Andrew. MN church denies family communion over son's gay marriage support. $11 / 15$, 2012. http://www.towleroad.com/2012/11/mn-churchdenies-entire-family-communion-over-gay-marriage-support.html (accessed 02 23, 2013). 
Bible Study Tools. Biblical Theology. 2011.

http://www.biblestudytools.com/dictionaries/bakers-evangelical-

dictionary/biblical-theology.html (accessed 1 13, 2013).

blogger. Should gay men be able to take communion? 052011.

http://forums.catholic.com/showthread. php?t=564664 (accessed 02 09, 2013).

Boswell, John. Christianity, Social Tolerance and Homosexuality. Chicago and London: The University of Chicago Press, 1980.

Brittanica. Sexual Dimorphism. 2011.

http://www.britannica.com/EBchecked/topic/537133/sexual-dimorphism (accessed 02 01, 2013).

browntranslaments. Gender Queer (blog). http://genderqueer.tumblr.com/post/759427251/homonormativity (accessed 10 15, 2012).

Brom, Robert H. "Who can receive communion?" Catholic Answers. STL, Censor

Librorum Bernadeane Carr. $08 / 10,2004$. This is not acceptable dating—needs to August 10, 2004 or $08 / 10 / 2004$.

http://www.catholic.com/tracts/who-can-receive-communion (accessed 11 20, 2012).

Brooten, Bernadette J. Love Between Women. Chicago, IL: The University of Chicago Press, 1996.

Center, UC Berkeley Gender Equity Resource. Gender Equity Resource Center. N/A. http://geneq.berkeley.edu/Igbt_resources_definiton_of_terms (accessed 08 19, 2012). Again, if there is no author, then the article takes its place-but if there was a term looked up here, the term in quotes, goes first.

Charles D. Myers, Jr. "What the Bible Really Says About Homosexuality." Anima 1. 1 (1974): 21.

Cheng, Patrick S. Radical Love. New York, NY: Church Publishing Incorporated, 2011.

Countryman, L. William. Dirt Greed and Sex: Sexual Ethics in the New Testament and their Implications for Today. Philadelphia, PA: Fortress Press, 1988. 
Coogan, Michael D. A Brief Introduction to the Old Testament. Oxford: Oxford University Press, 2009.

Costen, Melva Wilston. What do Presbyterians believe about Communion? http://www.presbyterianmission.org/ministries/today/sacraments/ (accessed 0123,2013 ).

Crannell, Philip Wendell. "defile; defilement." No need for italics http://bibleencyclopedia.com/defile.htm (accessed 01 26, 2013).

Exodus International. Big Foot, Nessie \& Exodus International. 10 09, 2009. http://exodusinternational.org/2009/10/big-foot-nessie-exodusinternational-2/ (accessed 01 07, 2013). ???

Evangelical Lutheran Church of America. "Social Statement on Human Sexuality: Gift and Trust." Human Sexuality: Gift and Trust. 2009. http://www.elca.org/Who-We-Are/Welcome-to-the-ELCA/Quick-Facts.aspx (accessed 11 20, 2012).

Elwell, Walter A. Biblical Theology. 1997. http://www.biblestudytools.com/dictionary/biblical-theology/.

Episcopal Church. "'What makes us Anglican? Hallmarks of the Episcopal Church".Episcopal Church. 2012. www.Episcopalchurch.org (accessed 10 13, 2012).

Duckworth, Chris. "A Pastor's Approach to Holy Communion." Living Lutheran. 2012. http://www.livinglutheran.com/seeds/a-pastors-approach-to-holycommunion.html\#.UMNfS-Oe8aC (accessed 11 2012, 21).

Dvorsky, George, and James Hughes. "Postgenderism: Beyond the Gender Binary." Institute for Ethics and Emerging Technologies, 2008. 44-57.

Davies, Christie. "Religious Boundaries and Sexual Morality." In Que(e)rying Religion: A Critical Anthology, by Gary David Comstock and Susan E Henking. New York: Continuum, 1999.

Davis, Ellen F. "Reasoning with Scripture." Anglican Theological Review 90. 3 (2008): needs page numbers, first to last. .

DignityUSA. Home. 2012. http://www.dignityusa.org/ (accessed 10 13, 2012). 
Futato, Mark D. "Because It Had Rained: A study of Genesis 2:5-7 with implications for Genesis 2:4-25 and Gen 1:1-2:33." Westminster Theological Journal 60 (1991): 1-21.

Fiorenza, Elizabeth Schussler. In Memory of Her: A Feminist Theological Reconstruction of Christian Origins. New York, NY: Crossroad, 1983.

Foucault, Michel. The History of Sexuality Volume 1. New York, NY: Random House, 1990.

-. The Order of Things: An Archaelogy of the Human Sciences. New York: Random House, 1970.

Gudorf, Christine E. "The Erosion of Sexual Dimorphism: Challenges to Religion and Religious Ethics." Journey of the American Academy of Religion 69. 4 ( 2001): 863-891.

Geertz, Clifford. The Interpretation of Cultures. New York: HarperCollins, 1973.

Goodstein, Laurie. "Vatican to Check U.S. Seminaries on Gay Presence." The New York Times, September 15, 2005.

Goss, Robert E. Jesus Acted Up: A gay and lesbian manifesto. San Francisco: Harper, 1993.

Goss, Robert E., and Mona West. Take Back the Word: A Queer Reading of the Bible. Cleveland, OH: The Pilgrim Press, 2000.

ISNA. FAQ. 2008. http://www.isna.org/ (accessed 01 22, 2013). ???

Hubbard, Thomas K. Homosexuality in Greece and Rome. Los Angeles, CA: University of California Press, 2003.

Harvey, J. Civilized Oppression. Lanham, MD: Rowman \& Littlefield Publishers, Inc., 1999.

Head, Tom. "Transphobia." Answers.com. http://civilliberty.about.com/od/gendersexuality/g/transphobia.htm (accessed 12 10, 2012).

Herdt, Gilbert. Same Sex: Different Cultures. Boulder, CO: Westview Press, 1997.

-. Third Sex Third Gender: Beyond Sexual Dimorphism in Culture and History. New York: Zone Books, 1996. 
In Bodily Citations: Religion and Judith Butler, edited by Ellen T. Armour and Susan M. St. Ville. New York: Columbia University Press.

Heterosexism in Contemporary World Religion: Problem and Prospect, edited by Marvin M. Ellison and Judith Plaskow. Cleveland, OH: The Pilgrim Press, 2007.

Institutionalized Homosexuality in Native North America." Sexual Meanings (N/A), 1981. I don't know what is what here. But there is not enough information.

Jung, Patricia Beattie, and Ralph F. Smith. Heterosexism: An Ethical Challenge. New York, NY: State University of New York Press, 1993.

Jones, James H. Alfred C. Kinsey. New York, NY: W.W. Norton \& Co., Inc., 1997.

Jones, Stanton L., and Mark A. Yarhouse. Ex-Gays? A longitudinnal study of religoiusly mediated change in sexual orientation. Downers Grove, IL: InterVarsity Press, 2007.

Jordan, Mark D. The Ethics of Sex. Malden, MA: Blackwell Publishing, 2002.

- The Invention of Sodomy in Christian Theology. Chicago and London: The University of Chicago Press, 1997.

-. The Silence of Sodom: Homosexuality in Modern Catholicsm. Chicago, IL: University of Chicago Press, 2000.

Kaiser, Robert. "What was the sin of Sodom?" IWG Online. http://www.iwgonline.org/docs/sodom.html (accessed 12 03, 2012).

Queer Ultraviolence. 2012. http://littleblackcart.com/QueerUltraViolence.html (accessed 10 13, 2012).

Lopez, Rene A. "A Study of Pauline Passages with Vice List." Bibliotheca Sacra 168 (July-Sept 2011): 301-316.

.Narth Mission Statement. http://narth.com/menus/mission.html (accessed 01 10, 2013).

Nelson, Randolph A. "Homosexuality and Social Ethics." Word and World V. 4 (1981): needs page numbers. 
Norton, John. Vatican says 'sex-change' operation does not change person's gender. National Catholic Reporter September 19, 2011.

http://ncronline.org/news/vatican-says-sex-changeoperation-does-not-change-persons-gender (accessed 01 23, 2013).

McKracken, Sky. Some hard truths about the UMC, including that homosexuality isn't to blame. 06 18, 2012.

http://www.unitedmethodistreporter.com/2012/06/some-hard-truths-aboutthe-umc-including-that-homosexuality-isnt-to-blame/ (accessed 0408 , 2013).

Maxwell, David. "Gays okay in the PC(USA)". Gathering Voices. May 15, 2011. http://blog.thethoughtfulchristian.com/2011/05/gays-okay-in-thepcusa.html (accessed 11 20, 2012).

Maan, Tony. "The Eucharistic Presence of Christ in Seventeenth Century Dutch Protestant Popular Piety: Toward a Catholic-Protestant rapprochement?" Journal of Ecumenical Studies 43. 4 (2008): need page \#.

Margevicius, Rev. Thomas. The Mass - Part 5: What happens during the Communion rite? No, not italics, but quotation marks.2011. http://rediscover.archspm.org/belonging/topic.php?id=7246 (accessed 02 09, 2013).

Martos, Joseph. What are Sacraments? 2012. http://www.americancatholic.org/newsletters/cu/ac0895.asp (accessed October 13, 2012).

Home. Matropolitan Community Church. 2012. www.mccchurc.org (accessed 10 13, 2012).

Mclntosh, Peggy. "White Privilege: Unpacking the Invisible Knapsack." Wayne State University. 1990. http://ted.coe.wayne.edu/ele3600/mcintosh.html (accessed 10 13, 2012).

McNeil, John J. Taking a Chance on God. Boston, MA: Beacon Press, 1996.

-. The Church and the Homosexual. Boston, MA: Beacon Press, 1976.

"The Bible and Homosexuality." Booklet, MCCspell out, 2000.

Moran , Martin. Malakoi and Arsenokoitoi. http://lakeweedatarrowhead.net/index.htm (accessed 01 23, 2013)

Hinze, Christine Firer, and J. Patrick Hornbeck II, eds. . "More Than a Monologue: Sexual Diversity and the Catholic Church." More Than a Monologue. Bronx: Fordham University Press, forthcoming. 1-122 ms. 
Olyan, Saul. "And with a male you shall not lie the lying down of a woman: Meaning and significance of Leviticus 18:22 and 20:13." Journal of the History of Sexuality 5 (1994): 179-206.

Peter Kirby. "Didache." Early Christian Writings. 2012. http://www.earlychristianwritings.com/text/didache-roberts.html (accessed November 21, 2012).

Pickett, Brent. Definition of Homosexuality. Feb 11, 2011. http://plato.stanford.edu/entries/homosexuality/ (accessed 08 12, 2012).

Pickett, Brent L. Historical Dictionary of Homosexuality: Religions, Philosophies, and Movements. Lanham, MD: Scarecrow Press, Inc., 2009.

Porter, Stanley E, and Craig A. Evans. "Vice and Virtues List in the NT." Dictionary of New Testament Background : A Compendium of Contemporary Biblical Scholarship.Downers Grove, IL: InterVarsity Press, 2000.

Presbyterian Church USA. "A Study Guide for Policy Statements and Recommendations from the 1978 Report "The Church and the Homosexual"." PC USA. 2006.

http://www.pcusa.org/media/uploads/theologyandworship/pdfs/definitive guidance.pdf (accessed November 20, 2012).

Super, John T., and Lamerial Jacobson. "Religious Abuse: Implications for counseling lesbian, gay, bisexual, and transgender individuals." Journal of LGBT Issues in Counseling 5. 3-4 (2011): 180-196.

Schwartz, Regina M. The Curse of Cain. Chicago and London: The University of Chicago Press, 1997.

Schori, Katherine Jefferts. "Episcopal Church Presiding Bishop Katharine Jefferts Schori concerning proposed bill in Uganda." Episcopal Church. 2012. http://www.episcopalchurch.org/notice/episcopal-church-presidingbishop-katharine-jefferts-schori-concerning-proposed-bill-uganda (accessed November 20, 2012).

Severson, Kim. Backed by State Money, Georgia Scholarships Go to Schools Barring Gays. 1 20, 2013. http://www.nytimes.com/2013/01/21/education/georgiabacked-scholarships-benefit-schools-barring-gays.html?_r=0 (accessed January 26, 2013). 
Sedwick, Eve Kosofsky. Epistemology of the Closet. Berkeley, CA: University of California Press, 2008.

Siker, Jeffrey S., ed. Homosexuality in the Church. Louisville, KY: Westminster John Knox Press, 1994.

Soulforce. 2012. http://soulforce.com/ (accessed 08 26, 2012).

Spade, Dean. Normal Life. Cambridge, MA: South End Press, 2011.

Stuart, Elizabeth. "Sacramental Flesh." In Queer Theology, 65-75. Loughlin, 2003.

Rhinehart, Michael. "Compassion and Understanding." Living Lutheran. 2012. http://www.livinglutheran.com/blog/2010/10/compassion-andunderstanding-1.html\#.UMNeb-Oe8aA (accessed 11 21, 2012).

Roxie, Marilyn. What is Genderqueer? 12 30, 2011. http://genderqueerid.com/what-is-gq (accessed 08 15, 2012).

Roberts, Scott. "Catholic Archbishop of San Francisco: Allowing gays to marry 'is like legalising male breastfeeding'." Pink News, January 29, 2013.

Terrence. Queering Genesis: "Male and Female (And Others) He Created Them". April 01, 2011. http://myqueerscripture.blogspot.com/2011/04/queering-genesis-andfemale-and-others.html (accessed March 05, 2013).

Tucker, Karen B. Westerfield. American Methodist Worship. New York, NY: Oxford University Press, 2001.

The United Methodist Church. "What is the denomination's position on homosexuality?" Our Faith Mission and Ministry. 2008. http://archives.umc.org/interior.asp?mid=1324 (accessed 11 21, 2012).

The Domestic and Foreign Missionary Society. Holy Communion. 2012. http://www.episcopalchurch.org/page/holy-communion (accessed 022 , 2013).

Thomas, Robert L. "Dynamic Equivalence: a method of translation or a system of hermeneutics?" TMS University. http://www.tms.edu/tmsj/tmsj1g.pdf (accessed 11 1, 2012).

Truluck, Rembert. "Spiritual Violence”. 2001. http://www.whosoever.org/v5i6/violence.html (accessed 10 13, 2012). 
Weinberg, George. Society and the Healthy Homosexual. Garden City, NY: Anchor Books, 1973.

West, Rev. Dr. Mona. "Coming Out as Sacrament." MCC Church. http://mccchurch.org/download/theology/sexandspirit/ComingOutSacram ent.pdf (accessed 10 13, 2012).

Weston, John-Henry. "New Jersey Archbishop Myers: Catholics who back gay 'marriage' should not receive Holy Communion." Lifesite News, 9 27, 2012. Needs more data-website address and access date?

White, Rev. Dr. Mel. "What the Bible says - and Doesn't say- about Homosexuality." Soulforce. How to find?

Wilburn, Ralph G. "A Theology of the Sacraments." Mid-Stream 5. 2 (1966). 